\title{
Institutional Investors and Private Equity*
}

\author{
KASPER MEISNER NIELSEN \\ Copenhagen Business School and CEBR
}

\begin{abstract}
Entrepreneurial finance literature has highlighted that institutional investors are the main contributors to private equity funds. This paper complements these findings by documenting that institutional investors also invest directly in private equity. A major concern for such investments is the higher agency costs associated with private equity. We show that institutions invest in private firms with governance mechanisms that tend to reduce the expected agency costs and risk of minority expropriation. Good governance mechanisms further allow institutional investors to enjoy the benefits of syndication and thereby reduce idiosyncratic risk. In addition, we show that institutional investments tend to be followed by further improvements in corporate governance and tend to occur in high-growth firms within research and development intensive industries.
\end{abstract}

JEL Classification: G20, G24, G32

\section{Introduction}

Private equity investments have, over the last two decades, been the fastest growing market for corporate finance (Fenn et al., 1997). The increasing importance of private equity has fostered a growing academic literature, which has identified three main sources of entrepreneurial finance: venture capital (VC), angel investors, and corporate investments. ${ }^{1}$ Interestingly, the vast majority of papers deal with $\mathrm{VC}$, whereas few papers have analyzed the

\footnotetext{
* I thank two anonymous referees, Tom Berglund, Denis Gromb, Hans Christian Kongsted, Darius Miller, Nikolaj Malchow-Møller, Marco Pagano (the editor), Ludovic Phalippou, Jesper Rangvid, Thomas Rønde, Annette Vissing-Jørgensen, and seminar participants at the "Alternative Views on Corporate Governance Conference" in Zurich 2006, the Financial Intermediation Research Society's Conference in Shanghai 2006, and University of Copenhagen. This project has been financially supported by CEBR (www.cebr.dk) and the Economic Policy Research Network.

1 For a detailed survey of the entrepreneurial finance literature, see Denis (2004); Gompers and Lerner (2000a) offer a detailed survey of the VC cycle.
} 
two alternative sources of entrepreneurial finance. ${ }^{2}$ This is, in part, due to the difficulty of obtaining data, as noted by Fenn et al. (1997), since data mainly are provided by specialized agencies (e.g. Venture Economics, Venture One) that tend to focus on high-tech, high-growth industries where VC financing is dominant.

On the financing side, VC literature has shown that institutional investors and, in particular, pension funds are the primary financing source of VC funds. Gompers and Lerner (2000a) show that institutional investors account for around 60 percent of the annual US VC fundraising between 1990 and 1997, whereas Bottazzi and Da Rin (2002) report that institutional investors in Europe have committed between 15 and 34 percent of the total annual funding. Despite these large investments in VC, we have only a limited understanding of the channels that institutional investors use to provide entrepreneurial firms with financing. This is partly due to a widespread view in the $\mathrm{VC}$ literature that institutional investors generally choose to invest in private equity through funds. As an example, Lerner et al. (2007) argue that the bulk of institutional investment in private equity is done through funds, since institutions lack the intensive relationship and due diligence skills needed to directly select the appropriate private equity investments. Moreover, they argue that institutions do not have resources to intensively monitor a portfolio of private firms. Whereas direct investments by institutions are likely to be limited due to these obstacles, this claim might not be universally true. In particular, direct investments by institutions might be absent only in the subsample of hightech, high-growth firms scrutinized by VC literature, which are likely to require more information and expertise than the average private firm. Instead, for the generality of private firms, institutional investors might be a direct source of financing - a role that, to our knowledge, is unexplored by the literature. This paper fills this gap.

We make use of a unique dataset of the universe of privately held corporations with limited liability in Denmark. The data are based on filings of annual reports to the Danish Ministry of Economic and Business Affairs. These annual reports include items from the income statement and balance sheet, the ownership structure, and name of the CEO and board members - all of which privately held firms in Denmark are required to make public by law.

This dataset allows us to study two novel issues. First, we document that institutional investors do indeed make significant direct investments in private equity. We find that institutional investors own between 2.2 and 2.9 percent of all nonfinancial private equity when weighted by the book value of assets.

2 The main exceptions are Wong (2002), who analyze angel finance, and Hellmann (1998) and Gompers and Lerner (2000b), who evaluate the performance of corporate venture investments. 
Due to the size of this market, these direct investments are significant. In 2003, the book value of the institutions' direct investments in nonfinancial firms was 2.4 billion Euros. In comparison, the Danish VC and buy-out funds, in total, had 2.2 billion Euros under management in 2003 (Vækstfonden, 2003). Second, given their investments in private equity, we find strong evidence of an institutional preference for companies with governance mechanisms that tend to reduce the potential for expropriation of minority investors. Thus, a major concern for institutional investors is the higher agency costs associated with private equity investments (See Easterbrook and Fischel, 1986; O'Neal, 1987; a.o.) To identify companies in which minority expropriation is less likely, we use seven proxies for corporate governance mechanisms that make it harder for controlling shareholders to extract rent. We find that the probability of having an institutional investor among the owners of a particular firm is positively related to control dilution (absence of a single controlling owner), the CEO being an outsider, the potential for board representation (number of outside board members), voluntary provision of information, and incorporation under legal forms with better corporate governance provisions. Consistent with this, we also find that institutional ownership is negatively related to the number of inside board members and private benefits of control.

The finding that institutional investors fear expropriation in private firms complements recent evidence from the growing literature on investor preferences for certain firm characteristics (see Dahlquist and Robertsson, 2001; Giannetti and Simonov, 2006). These papers provide evidence from public equity markets suggesting that investors who enjoy only security benefits (e.g. institutional investors) fear minority expropriation by controlling shareholders, and tend to invest in companies with governance mechanisms that mitigate this risk.

In addition, we analyze the interaction between governance mechanisms and institutional syndication. The benefit of syndication is that it allows investors to diversify through risk sharing (Wilson, 1968), whereas the cost of syndication is the reduced monitoring intensity due to the free-riding problem (Pichler and Wilhelm, 2001). A priori, it is thus an open question whether syndication is a substitute or complement to governance mechanisms, since both costs and benefits of syndication are affected by agency costs. A novel feature of our data is that we can provide empirical evidence on this important issue. Indeed, our evidence clearly shows that institutional syndication occurs in firms with good governance mechanisms. This finding indicates that syndication and governance mechanisms are complements and suggests that agency problems in private firms are severe, since institutions enjoy the benefit of portfolio diversification only in firms with good governance mechanisms. 
We acknowledge the potential endogeneity of our proxies for the governance mechanisms that are intended to minimize minority expropriation. We address this problem by constructing a sample of firms where a new owner is introduced, and use the lagged governance characteristics to explain whether the new owner is an institutional investor. We find that our results are consistent with a causal effect of governance characteristics on institutional ownership. Moreover, our results are robust to controlling for other investment motives, such as portfolio diversification and investment opportunities, and to the bias that may arise in logistic regressions when the dependent variable (in our case the presence of institutional investors) measures a rare event.

We further examine the effects of institutional ownership on governance mechanisms, performance, and growth subsequent to the introduction of an institutional owner. We find evidence consistent with our main story: the average firm significantly improves its governance mechanisms after the introduction of an institutional owner. In addition, the evidence suggests that high-growth firms tend to attract institutional investors with deep pockets to finance future growth: firms with institutional ownership have negative industry-adjusted operating performance, but large excess growth in both assets and employees before and after the change in ownership. The magnitude of this excess growth seems to explain the documented underperformance. Thus, institutional investors selectively invest in high-growth firms with a need for external financing to fund future growth. On the surface these firms appear to have characteristics that are similar to firms that receive $\mathrm{VC}$ financing. Since institutional investors can choose whether to invest in such firms directly or indirectly through $\mathrm{VC}$ funds, this evidence begs the question of what determines this choice, and whether direct investments are associated with a more active involvement of institutional investors in the firms they invested in. These interesting issues are left to future research.

The paper proceeds as follows: In Section 2 we discuss institutional preferences for private equity investments. Section 3 details the unique data containing all privately held companies in Denmark. Section 4 presents the empirical strategy, and Section 5 summarizes our results. Finally, Section 6 offers some concluding remarks.

\section{Private Equity Investments}

Private equity investments have, over the last two decades, experienced a rapid growth (Fenn et al., 1997). A significant part of this growth has been encouraged by regulatory changes that have allowed pension funds to increase their investments in private equity. Another vehicle of this increasing activity 
has been the development of the limited partnership, where general partners invest the limited partners' contributed funds. ${ }^{3}$ However, whereas much of this growth has been fostered by the emergence of private equity funds, the bulk of private equity holdings still remains directly held by investors. In fact, Fenn et al. (1997) and Moskowitz and Vissing-Jørgensen (2002), show that $\mathrm{VC}$ fundraising accounts for a trivial fraction (less than 1 percent) of the entire private equity market.

The increased importance of private equity investments has recently gained attention within the academic literature, but the vast majority of papers deal entirely with $\mathrm{VC}$ or buy-out funds. ${ }^{4}$ Thus, the literature on private equity investments has almost exclusively dealt with private equity funds, despite the fact that these only constitute a small fraction of the entire private equity market. This gap is mainly due to the difficulties involved in obtaining data, as noted by Fenn et al. (1997), and partly due to the widespread view that the emergence of private equity funds has revolutionized the private equity market and limited direct investments by nonentrepreneurs. As a result, few papers have devoted attention to alternative sources of entrepreneurial financing: Wong (2002) shows that angel investors contribute substantial amounts of capital to entrepreneurial firms, ${ }^{5}$ and estimates the total angel investor market to be twice as large as the independent VC market. Similarly, corporations invest directly in private equity for financial and/or strategic reasons. Hellmann (1998) estimates that corporations' organized VC programs account for around 5 percent of total VC investments. However, this estimate might be significantly downward biased, since it does not take the direct ownership of firms with less formally organized investments into account.

This paper provides additional evidence on alternative financing sources by showing that institutional investors invest directly in private equity. Interestingly, Lerner et al. (2007) highlight that institutions do not have the resources to intensively monitor a portfolio of private firms and that efforts to invest jointly have frequently been hindered by agency problems. As a result, they suggest that the bulk of institutional investment in private equity in the US is done through funds. Whereas this is likely to be true for samples of high-tech, high-growth firms, the current paper shows that institutions have invested significant amounts in the population of private firms in Denmark. One immediate concern with this finding is that direct investments in private equity might be specific to Denmark. However, a recent survey of institutional

\footnotetext{
3 See Fenn et al. (1997) and Gompers and Lerner (2000a) for a comprehensive historical overview of the development of the private equity market.

4 See Gompers and Lerner (2000a, 2001) and Denis (2004) for recent surveys.

5 The term "angel investors" refers to wealthy individuals who invest directly in a small set of companies.
} 
investors' private equity allocations in the Netherlands by Cumming and Johan (2007) shows that 20 percent of the average private equity portfolio in 2005 is directly held. ${ }^{6}$ Moreover, recent coverage in the business media reports evidence of direct investment by some of the largest institutional investors in Australia, Canada, Germany, the Netherlands, Switzerland, Turkey, and the UK. ${ }^{7}$ Given the magnitude of this phenomenon, it is worthwhile to investigate which factors may drive the choices of institutional investors in their direct private equity investments.

\subsection{DETERMINANTS OF INSTITUTIONAL INVESTMENTS IN PRIVATE EQUITY}

\section{Agency Costs}

A major issue facing potential investors in privately held corporations is the expropriation of minority shareholders by controlling shareholders (Easterbrook and Fischel, 1986; O'Neal, 1987). In general, the ownership of privately held corporations is concentrated, which implies that owners have sufficient control to monitor and discipline management. ${ }^{8}$ The prevalent agency problem thereby shifts from the classical agency problem between management and shareholders analyzed by Jensen and Meckling (1976), to conflicts between controlling and noncontrolling owners (see Shleifer and Vishny, 1997; among others).

In particular, the fear of minority expropriation is important for institutional investors, since they are, by law, prohibited from being controlling owners and from participating in a controlling coalition. ${ }^{9}$ Recent evidence suggests that institutional investors fear expropriation even in publicly held firms. Using data from Sweden, Giannetti and Simonov (2006) find that the probability of investing in a company with weak governance mechanisms is significantly lower for both foreign and domestic institutions and that the effect is larger than for individual investors. This finding suggests that institutions should be even more concerned with governance arrangements in private firms, since listed firms are constrained to have uniformly better governance by law,

\footnotetext{
${ }^{6}$ Interestingly, Cumming and Johan (2007) also show that Dutch institutional investors plan to hold 18 percent of the private equity portfolio directly in the future.

7 Financial Times, November 7, 2005: "Pension Funds Bypass Private Equity Houses" and FT Mandate, February 2006 Issue: "Boost for Private Route".

8 Bennedsen et al. (2003) document that concentrated ownership is dominant in closely held corporations in Denmark. More than 95 percent of the firms have less than five owners.

9 In most countries around the world, institutions are prohibited from being controlling owners of nonfinancial firms. The (well known) exceptions are Germany and Japan, where banks are allowed to be controlling owners.
} 
and public equity markets provide institutions with a venue where they can liquidate their investment if dissatisfied with the conduct of management.

As a solution to the potential squeeze-out of minority investors in private firms, both legal scholars (O'Neal and Thompson, 1985) and the finance literature (Pagano and Röell, 1998; Bennedsen and Wolfenzon, 2000; Gomes and Novaes, 2005; a.o.) have suggested to dilute control, so that no shareholder can take unilateral actions to obtain private benefits at the expense of other owners. Another way to mitigate this potential risk is to invest in firms with governance mechanisms that make the operations of the company more transparent to minority shareholders. Transparency is important, since privately held firms are not required to disclose the same information as publicly held ones, e.g. private firms are not obliged to disclose any major news affecting the firm's business. For instance, in Denmark, their only disclosure obligation is the yearly publication of the annual accounts. ${ }^{10}$ Thus, the provision of information by privately held firms is by no means comparable to that by firms that are publicly traded.

In sum, institutional investors are minority investors by definition. Consequently, their investments should be placed in firms where expected agency costs are minimized if they fear expropriation by controlling shareholders.

\section{Portfolio Diversification and Investment Opportunities}

Today, institutional investors invest in a variety of financial and real assets to form a well diversified portfolio. In this choice, their risk-return trade off could be improved by including private equity in the portfolio. The potential role of private equity depends on the extent to which the returns to private equity investments co-move with the market. Hwang et al. (2005) show that a mean-variance investor would want to invest a positive, but small, fraction in private equity. The positive portfolio weight on private equity is driven by a low correlation with the stock market return - a relationship that has been questioned in the literature: Using data from Hwang et al. (2005), Woodward (2005) shows that the correlation coefficient is significantly negatively biased by the stale pricing problem. When correcting this, the correlation between private and public equity returns triples. In a similar vein, Moskowitz and Vissing-Jørgensen (2002) find a correlation of 0.7 between the book equity return of public and private equity from 1963 to 1999, whereas Phalippou and Zollo (2005) find that the performance of private equity funds co-varies positively with both business cycles and stock market returns.

$\overline{10}$ In many countries (e.g. United States), privately held firms are not obliged to disclose any information to the general public. 
From the perspective of institutional investors, this is clearly an unattractive property. Even though these findings suggest a limited benefit of adding private equity to their portfolio, institutions might still invest in private equity if this market offers investment opportunities (e.g. new technologies) that are unmatched by the public equity market. Thus, institutional investments in private equity might be driven be portfolio diversification and investment opportunities.

\section{Data}

We use a unique firm-level dataset of privately held firms in Denmark with yearly observations from 1996 to 2003. The data originate from the firms' filing of their annual reports to the Danish Ministry of Economic and Business Affairs, which is compulsory for all limited liability companies in Denmark. Thus, the data include the entire population of Danish limited liability firms and consist of items from the income statement and balance sheet and information on the identity of managers, board members, and owners. This detailed dataset enables us to investigate the determinants of institutional investments in private equity.

The first objective is to document the extent to which institutions invest directly in privately held firms. The number of firms with limited liability in Denmark in each year varies between 32,000 and 47,000. These data include consolidated firms only, as we exclude all fully owned subsidiaries. We then identify firms in which institutional investors are among the owners. The ownership information is obtained from the annual reports, where firms are obliged to disclose the full identity of any shareholder with an ownership stake of 5 percent or more. Due to the extremely concentrated ownership in closely held corporations, we thereby obtain the full ownership structure for most firms. From the ownership information, we identify institutional investors, i.e. banks, insurance companies, and pension funds. We use the fact that the institutional investors are also included in the dataset to identify the population of institutional investors and then use a unique firm-ID to measure institutional ownership very accurately.

The distribution of firms and the presence of institutional investors in each year from 1996 to 2003 are shown in Table I. ${ }^{11}$ The left side of the table shows the total number of firms, the number of firms with an institutional investor among the owners, and the average number of institutions in firms with at least one institutional investor among the owners. The right side of Table I shows

\footnotetext{
11 Note that we eliminate fully owned subsidiaries due to the consolidation of the firm-level data. Thus, subsidiaries of financial institutions are not included in Table I.
} 
the same statistics for the subsample that excludes firms operating within financial intermediation and real estate. ${ }^{12}$ This subsample allows us to focus on direct investments by institutional investors beyond their core business area. We thereby exclude firms in which institutional investors are allowed to be controlling owners and focus on firms where they are minority investors.

Panel A in Table I shows that the number of institutional investments is generally constant in the period from 1996 to 2003 for both samples. Similarly, the average number of institutions in the firms with institutional owners is fairly constant across years. ${ }^{13}$ Panel $\mathrm{B}$ in Table I shows a breakdown by industries for 1999. We use the industry classifications provided by Venture Economics to make the descriptive statistics comparable to the VC literature. ${ }^{14}$ Interestingly, most direct investments are not in industries where one normally observes venture capitalists (i.e. computer-related and research and development-intensive industries). ${ }^{15}$

Figure 1 shows the distribution of institutional ownership in nonfinancial firms with institutional investment in $1999 .{ }^{16}$ In total institutional investors have invested in 265 firms in 1999. Institutional ownership stakes of 5, 10, 25,33 and 50 percent are fairly common as they make up almost half of the observations (116 out of 265). The remaining observations seem fairly uniformly distributed within the interval between 5 and 50 percent.

In Table II, we report the institutions' ownership share of the total value of nonfinancial firms weighted by the book value of assets. As a benchmark, we further report the institutional investors' share of the total market value of (domestic) nonfinancial firms listed on the Copenhagen Stock Exchange.

Panel A in Table II shows that institutional investors' direct ownership accounts for around 2.5 percent of the total assets of nonfinancial firms.

\footnotetext{
12 Inter alia, we exclude firms operating in industries within the two-digit NACE codes 65 (financial intermediation), 66 (insurance and pension funds), 67 (activities auxiliary to financial intermediation) and 74 (real estate).

13 The reduction in the average number of institutional investors from the sample of all firms to the sample of nonfinancial firms is due to a significant number of real estate syndicates, where a group of pension funds jointly manage a real estate company.

14 The Venture Economics' industry classifications (unfortunately) do not correspond one-toone to SIC or (the European equivalent) NACE industry codes. To mitigate this problem, we have created the additional industry "research \& development," since the SIC and NACE industry classifications do not disaggregate research and development-intensive industries. As a result, we have excluded "biotechnology," since it is included in the research and development category.

15 Gompers and Lerner (2001) report that 60 percent of all VC in the 1990s went to information technologies. Similar numbers are reported in Wong (2002) for angel financing.

16 Note that we only observe ownership stakes above 5 percent, as 5 percent is the threshold, where firms are obliged to report the identity of their owners in the annual report.
} 
Table I. Institutional investors' direct investments in private equity, 1996-2003

This table depicts the level of direct investments in private equity by institutional investors in Denmark from 1996 to 2003. All firms is the population of privately held firms with limited liability in Denmark, whereas nonfinancial firms excludes the financial firms where institutional investors are allowed to be controlling owners. Financial firms operate within two-digit NACEindustry codes 65, 66, 67 and 74 (i.e. financial intermediation and real estate). Panel A shows the total number of firms, the number of firms with institutional investments and the average number of institutional investors in firms with institutional investments (average number of II) from 1996 to 2003. Panel B breaks the investments in 1999 down into industries. We use the industry classifications provided by Venture Economics (see Section 3 for details).

\begin{tabular}{|c|c|c|c|c|c|c|c|c|}
\hline & \multicolumn{4}{|c|}{ All firms } & \multicolumn{4}{|c|}{ Nonfinancial firms } \\
\hline & \multirow[b]{2}{*}{$N$} & \multicolumn{3}{|c|}{$\begin{array}{l}\text { Firms with institutional } \\
\text { investments (II) }\end{array}$} & \multirow[b]{2}{*}{$N$} & \multicolumn{3}{|c|}{$\begin{array}{l}\text { Firms with institutional } \\
\text { investments (II) }\end{array}$} \\
\hline & & $N$ & $\%$ & $\begin{array}{c}\text { Average } \\
\text { number of II }\end{array}$ & & $N$ & $\%$ & $\begin{array}{c}\text { Average } \\
\text { number of II }\end{array}$ \\
\hline \multicolumn{9}{|c|}{ A: Number of firms and institutional investments by year } \\
\hline 1996 & 32,790 & 374 & 1.1 & 2.01 & 26,951 & 269 & 1.0 & 1.95 \\
\hline 1997 & 34,889 & 363 & 1.0 & 1.96 & 27,976 & 261 & 0.9 & 1.90 \\
\hline 1998 & 36,461 & 337 & 0.9 & 1.94 & 28,274 & 251 & 0.9 & 1.82 \\
\hline 1999 & 39,121 & 386 & 1.0 & 2.03 & 28,700 & 265 & 0.9 & 1.88 \\
\hline 2000 & 40,452 & 394 & 1.0 & 2.01 & 27,733 & 274 & 1.0 & 1.87 \\
\hline 2001 & 42,542 & 423 & 1.0 & 1.90 & 28,393 & 293 & 1.0 & 1.80 \\
\hline 2002 & 43,606 & 434 & 1.0 & 1.89 & 29,285 & 297 & 1.0 & 1.75 \\
\hline 2003 & 47,538 & 414 & 0.9 & 1.96 & 31,861 & 266 & 0.8 & 1.84 \\
\hline \multicolumn{9}{|c|}{ B: Number of firms and institutional investments by industries in 1999} \\
\hline Communications & 151 & 2 & 1.3 & 3.50 & 151 & 2 & 1.3 & 3.50 \\
\hline Computer related & 712 & 18 & 2.5 & 2.28 & 712 & 18 & 2.5 & 2.28 \\
\hline Other electronics & 250 & 2 & 0.8 & 2.00 & 250 & 2 & 0.8 & 2.00 \\
\hline Research \& development & 33 & 10 & 30.3 & 2.20 & 33 & 10 & 30.3 & 1.50 \\
\hline Medical \& health related & 1,097 & 3 & 0.3 & 1.67 & 1,097 & 3 & 0.3 & 1.50 \\
\hline Energy & 20 & 2 & 10.0 & 1.00 & 20 & 2 & 10.0 & 1.00 \\
\hline Consumer products & 10,742 & 45 & 0.4 & 1.42 & 10,742 & 45 & 0.4 & 1.46 \\
\hline Industrial products & 2,173 & 25 & 1.2 & 2.12 & 2,173 & 25 & 1.2 & 1.62 \\
\hline Transportation & 1,498 & 7 & 0.5 & 1.29 & 1,498 & 7 & 0.5 & 1.29 \\
\hline Other industries & 22,445 & 272 & 1.2 & 2.12 & 12,024 & 151 & 1.3 & 1.93 \\
\hline All & 39,121 & 386 & 1.0 & 2.03 & 28,700 & 265 & 0.9 & 1.88 \\
\hline
\end{tabular}

Table II also shows that from 1996 to 2003, the direct institutional ownership share of private equity slightly decreased from around 2.8 to 2.3 percent. Interestingly, the direct institutional ownership share in the market for private equity is significantly smaller than for public equity. This suggests that agency and transaction costs are important issues for institutional investors when 


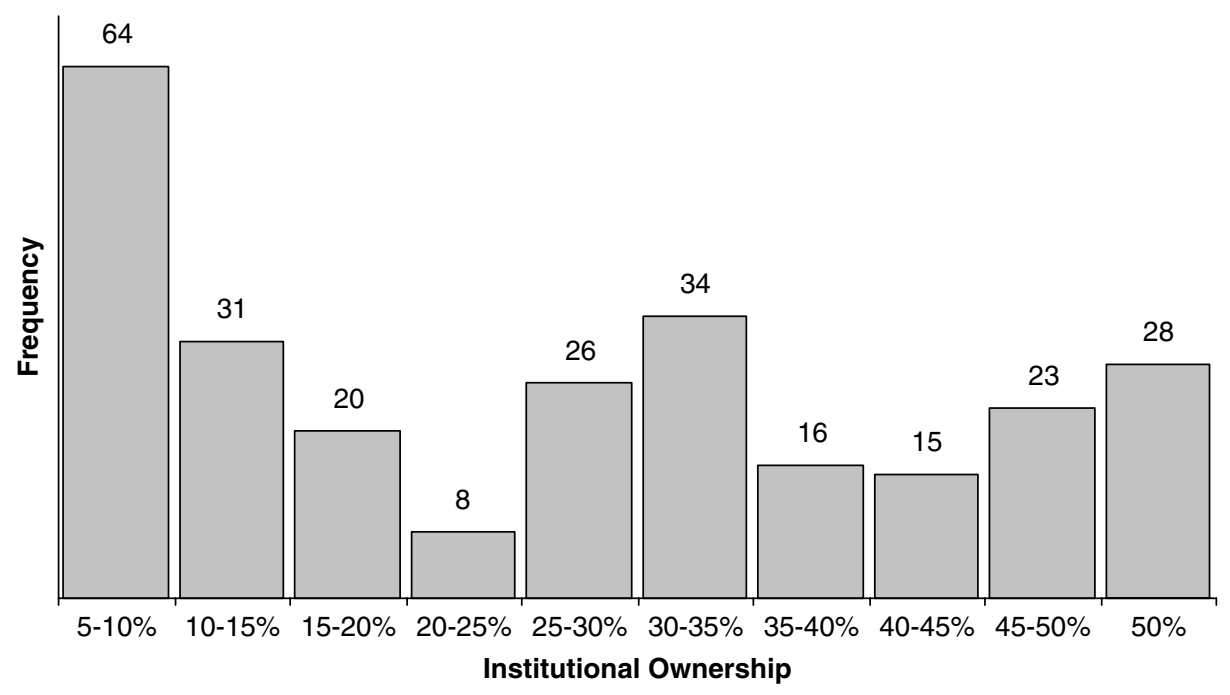

Figure 1. Distribution of institutional ownership in the 265 nonfinancial firms with institutional investments in 1999. Note: We only observe ownership stakes above 5 percent, as 5 percent is the threshold, where firms are obliged to report the identity of their owners in the annual report.

they allocate their investments into equity. Panel B shows that when we look at the decomposition by industries, the institutional ownership share is highest in "Research and development" with 15.2 percent of the assets. Thus, when we value-weight the investments, institutional investors have the highest ownership share in industries that also attract venture capitalists (Gompers and Lerner, 2001). Interestingly, there seems to be no apparent correlation in the pattern of investments across industries in public and private equity. Finally, Panel $\mathrm{C}$ shows the distribution of institutional investors by type of institution. Private equity investments are mainly held by banks and pension funds. Pension funds hold around 50 percent of the institutions' total private equity investments, whereas banks account for 37 percent.

\section{Empirical Strategy}

\subsection{ESTIMATION METHOD}

We start the analysis of the determinants of institutional investments in private equity by modeling the probability of institutional investors investing in firm $i$. The dependent variable is binary and equals 1 if there is an institutional 
Table II. Direct institutional ownership of private and public equity, 1996-2003

This table shows the direct institutional ownership share of private and public nonfinancial firms in Denmark. Private equity is weighted by book value of assets, whereas public equity is weighted by market capitalization. Panel A shows the direct institutional ownership share for each year from 1996 to 2003, whereas Panels B and C show the direct institutional ownership share by industries and type of institutional investor in 1999, respectively.

\begin{tabular}{|c|c|c|}
\hline & Private equity & Public equity \\
\hline \multicolumn{3}{|c|}{ A: Direct institutional ownership by year $(\%)$} \\
\hline 1996 & 2.8 & 29.7 \\
\hline 1997 & 2.9 & 27.6 \\
\hline 1998 & 2.5 & 31.9 \\
\hline 1999 & 2.5 & 29.4 \\
\hline 2000 & 2.6 & 27.4 \\
\hline 2001 & 2.3 & 25.4 \\
\hline 2002 & 2.2 & 23.1 \\
\hline 2003 & 2.3 & 18.8 \\
\hline \multicolumn{3}{|c|}{ B: Direct institutional ownership by industries in $1999(\%)$} \\
\hline Communications & 1.0 & 26.1 \\
\hline Computer related & 2.3 & 24.0 \\
\hline Other electronics & 0.9 & 43.9 \\
\hline Research \& development & 15.2 & 20.2 \\
\hline Medical \& health related & 0.8 & 27.6 \\
\hline Energy & 0.6 & 41.7 \\
\hline Consumer products & 0.6 & 39.5 \\
\hline Industrial products & 2.8 & 23.2 \\
\hline Transportation & 0.8 & 19.7 \\
\hline Other industries & 6.6 & 28.3 \\
\hline All & 2.2 & 29.4 \\
\hline \multicolumn{3}{|c|}{ C: Direct institutional ownership by type of institution in $1999(\%)$} \\
\hline Banks & 37.3 & 20.5 \\
\hline Mutual funds & 4.5 & 5.0 \\
\hline Insurance companies & 8.6 & 30.1 \\
\hline Private pension funds & 27.4 & 16.0 \\
\hline Public pension funds & 22.2 & 28.4 \\
\hline All & 100.0 & 100.0 \\
\hline
\end{tabular}

investor among the owners, and 0 otherwise. We estimate the probability of institutional investments using a logit model. ${ }^{17}$

We further extend the analysis to the determinants of institutional syndication. Syndication among financial institutions is a well-known

17 Our results are not affected by our choice of the (general) logit model. Even though the distribution of the dependent variable is highly skewed, we obtain quantitatively similar results when using a probit model. These results are available upon request. 
phenomenon in the underwriting of equity issues and commonly used by venture capitalists in entrepreneurial investments (Gompers and Lerner, 2000a; Kaplan and Strömberg, 2003; a.o.). We therefore proceed by analyzing syndication by institutional investors in the subsample of firms with institutional investment. We use two specifications to analyze the determinants of syndication. First, we estimate the probability of syndication in a logit model where the dependent variable is an indicator for institutional syndication, which equals 1 if there is more than one institutional investor. Second, we estimate the determinants of the number of institutional investors using an ordered logit model. ${ }^{18}$

In the analysis, we estimate the determinants of institutional ownership using the cross-section of data for each year from 1996 to 2003 separately. In principle, we have panel data, but we cannot use error component models due to limited time variation in both the dependent and the explanatory variables of interest. ${ }^{19}$ In addition, panel data models implicitly assume that the institutional decision to enter or exit a given investment is symmetric.

Moreover, as in most corporate finance research, endogeneity problems ought to be addressed. In particular, one could argue that the governance characteristics in the cross-sectional analysis are endogenous. Following a reverse causality argument, the governance characteristics of a particular firm is an outcome of the ownership structure and, hence, we observe them because the firm has an institutional investor among the owners. This line of argument would lead to a relationship that is observationally equivalent to the hypothesis that governance characteristics are exogenous: in both cases, institutional investors end up investing preferentially in companies where the scope for expropriation of minority shareholders is minimized. We address the endogeneity issue by analyzing the determinants of institutional investment in the subsample of firms that have introduced a new owner in a given year. To induce causality, we regress institutional ownership on lagged explanatory variables. Thus, by construction, we limit the scope for the potential reverse causality story outlined above. To complete the analysis, we further shed light on the effects of institutional ownership on governance mechanisms and performance subsequent to an investment.

\footnotetext{
18 The results are not qualitatively affected by our choice of regression model. Alternatively, we could have analyzed the syndication of institutional investors using other discrete models such as the zero-inflated Poisson regression model.

19 Limited time variation in firms' governance characteristics is not an unequaled problem within the literature. For instance, Giannetti and Simonov (2006) find little time variation in governance characteristics of publicly held firms in Sweden from 1995 to 2001.
} 


\subsection{SPECIFICATION}

In the empirical analysis of the determinants of institutional investment, our specification includes as explanatory variables (a) a set of proxies for governance mechanisms and agency costs, and (b) a set of control variables designed to capture other investment preferences of institutional investors.

\section{Governance Mechanisms and Agency Costs}

We use seven firm-specific governance measures related to the potential conflict between the controlling and noncontrolling owners, which is the dominant agency problem in closely held corporations.

First, following the legal and finance literature on governance problems in privately held corporations (O'Neal and Thompson, 1985; Pagano and Röell, 1998; Bennedsen and Wolfenzon, 2000; Gomes and Novaes, 2005; among others), we include among the regressors an indicator variable for control dilution, which equals 1 in the absence of a single controlling owner who possesses more than 50 percent of the ownership. As the scope for minority expropriation is negatively related to control dilution, we expect a positive relationship between control dilution and institutional ownership.

Second, we include a dummy for whether the CEO is an owner. We argue that conflicts between controlling and noncontrolling owners are more likely to hurt the latter when the CEO is a powerful owner. In general, the ownership of privately held firms is extremely concentrated, which implies that owners have sufficient control to monitor and discipline an outsider CEO. Thus, from the perspective of minority investors, an outsider CEO is preferred to an insider.

Third, the explanatory variables include the number of insiders on the board. We define insider board members as the CEO and the owners of the firms. We expect the number of insider board members to be negatively related to institutional ownership, as insider dominated boards might increase the scope for expropriation (see Hermalin and Weisbach, 2003).

Fourth, we include the number of outsiders on the board. We expect a positive relationship between outsider board members and institutional ownership, since the probability of board representation and protection of minority interests are likely to increase with the number of outsider board members. A valid concern with the above specification (i.e. including both the number of insider and outsider directors) is that they measure the same effect with opposite signs. Perhaps a better specification would include the number of board members and the proportion of insiders on the board. However, in Denmark, having a board is compulsory only in firms incorporated under the 
A/S legal form, whereas it is voluntary in ApS-companies. ${ }^{20}$ Thus, for firms without a board, the ratio of insiders cannot be measured. ${ }^{21}$ We have therefore chosen the current specification to preserve observations.

Fifth, we attempt to measure private benefits of control. The previous literature has shown that the key difference in investment behavior seems to be between investors who enjoy only security benefits (e.g. institutional investors) and controlling shareholders who also enjoy private benefits (Dahlquist and Robertsson, 2001; Giannetti and Simonov, 2006). Moreover, private benefits can both be pecuniary and nonpecuniary. Pecuniary private benefits include self-dealing and dilution of corporate resources and are often referred to as "tunneling" (Johnson et al., 2000), whereas nonpecuniary private benefits include amenities and reputation (Demsetz and Lehn, 1985). To the best of our knowledge, few papers have succeeded in measuring private benefits of control at the firm level. ${ }^{22}$ One exception is Ehrhardt and Nowak (2003), who measure private benefits of control by including a dummy that equals 1 if the name of the firm includes the family name of an owner, the idea being that a closer link between family and corporate identity is reflected in the use of the family surname in the firm. A potential drawback of this measure of private benefits of control is that it may measure only nonpecuniary private benefits such as those stemming from "pride of ownership", rather than the extraction of pecuniary benefits at the expense of minority investors. The proxy might therefore capture particularly "proud" business owners who do not wish to have an institution among the owners, rather than firms in which institutions do not want to be owners. Since both of these cases lead to a relationship that is observationally equivalent, we acknowledge the potential problems associated with this way of measuring private benefits of control. For lack of a better measure, we nevertheless include it among our regressors.

Sixth, we include a dummy for whether the firm supplies voluntary information in their annual report. The law on annual reports obliges only very large firms to disclose their sales, whereas this is voluntary for smalland medium-sized firms. In fact, less than 2 percent of the closely held

$\overline{20}$ The A/S and ApS legal forms are the Danish equivalents to the US C-corp and S-corp, respectively.

21 If we restrict the sample to firms with boards, we obtain consistent results using the alternative specification: Board size is positive and significantly correlated with institutional ownership, whereas the coefficient on the ratio of insider directors is negative and significant.

22 Demsetz and Lehn (1985) investigate private benefits between industries within the US. They conjecture that certain industries (media and entertainment) are characterized by high private benefits of control (i.e. high amenity value). Other papers have looked at differences in private benefits between countries (Nenova, 2003; Dyck and Zingales, 2004; a.o.). These papers have used dual class shares and takeover premia to estimate private benefits of control. 
corporations in Denmark are obliged to disclose sales. Furthermore, there is a strong positive correlation between voluntary disclosure of sales and voluntary provision of other information. Thus, voluntary reporting of sales proxies for having a more informative annual report compared to firms that do not report sales. So, we define an information indicator that equals 1 if the firm reports sales in the annual report. Moreover, as all reports are required by law to be audited by external auditors, our information dummy captures firms that have chosen both to be more transparent to minority investors and have this information audited by the external auditor. ${ }^{23}$ Increasing transparency will therefore reduce the potential agency costs and limit the scope for minority expropriation.

Finally, we exploit that the dataset includes two different firm types (both with limited liability) with different legal obligations in terms of corporate governance provisions. Boards are compulsory in one type (A/S) and voluntary in the other (ApS). We therefore include a firm type dummy, which equals 1 for A/S-companies. This indicator variable captures the lower expected agency costs of incorporation under the A/S legal form, since the stricter regulation implies that managers and majority owners generally gain less power compared to ApS-companies.

\section{Other Determinants of Institutional Investors' Choices}

Previous literature on institutional investors and their investments in public equity (see Gompers and Metrick, 2001; Bennett et al., 2003; a.o.) has focused on three different preferences for stock characteristics: prudence, liquidity (or transaction costs), and historic return patterns (momentum). Prudence is related to the institutional investors' role as fiduciaries, since institutions are constrained by regulatory limits that might induce them to invest in less risky assets. The liquidity preference arises from the institutions' trading activity in the public equity market, which makes them more sensitive to transaction costs than other investors. The momentum motive has been suggested, since institutions might possess better information about historic return patterns or have a different preference for risk and return than other investors.

In the context of private equity investments where liquidity is limited, we therefore, control for firm characteristics that proxy for prudence and previous return when we investigate the determinants of institutional investments. We follow Del Guercio (1996) and Gompers and Metrick (2001), and consider three firm characteristics that may affect investment prudence: firm size, age,

\footnotetext{
23 Obviously, institutional investors can obtain information from sources other that the annual report. However, institutions are likely to prefer information from the annual report, as these are both free and reliable.
} 
and leverage. If institutional investors are prudent, they will prefer to invest in larger and older firms with low leverage, since these firms will be regarded as less risky. We include the current return on assets (RoA) to control for profitability. To make the profitability measure comparable across industries, we use the excess RoA defined as firm RoA in excess of the two-digit industry median.

We include controls for diversification motives and investment opportunities at the industry level, since these are difficult to measure on the firm level. ${ }^{24}$ To control for risk, we include the average beta within the industry. We estimate the beta of individual stocks using return data from the preceding 60 months. We then take the average at the two-digit industry level. For firms operating in industries with no public companies within the two-digit industry level, we use the average beta at the one-digit industry level. To control for investment opportunities, we include the average market-to-book ratio at the industry level. The market-to-book ratio is defined as the market value of equity plus book value of debt over book value of assets. Again, we take the average at the two-digit industry level and move to the onedigit if the industry is not represented on the Copenhagen Stock Exchange. Finally, the number of publicly traded companies on the Copenhagen Stock Exchange within the two-digit industry level is taken to measure the depth of the (domestic) public equity market within the industry. Countries with relatively small public equity markets (such as Denmark), tend to offer limited portfolio diversification, considering that investment in foreign assets is constrained by legal restrictions, exchange rate uncertainty, and home bias. ${ }^{25}$ Thus, for institutional investors, the private equity market might offer investment opportunities unmatched by the public equity market.

\section{Results}

\subsection{DETERMINANTS OF INSTITUTIONAL INVESTMENTS}

First, we model the probability of institutional investment in private equity by a logit model, where the dependent variable is a dummy for the presence of

\footnotetext{
24 Alternatively, we could opt to measure firm-level risk by the volatility of operating performance. However, as our data include only 8 years and a relatively large number of start-ups, the number of observations will be significantly reduced. We therefore include the firm-level risk measure among the controls as a robustness check in Section 5.5.

25 There exists a basic trade-off between the benefits of diversifying the portfolio internationally and increasing the risk from exchange rate uncertainty, since the future claims on the institutional investors' assets are in local currency. Hence, holding assets in the local currency will eliminate the exchange rate risk.
} 
institutional investors among the owners. This step provides insight into the determinants of institutional investments in privately held firms.

Table III lists the definitions of the explanatory variables that are used throughout the paper, and also provides descriptive statistics for 1999. The results from the first step of the analysis are reported in Table IV, which summarizes the results from the eight yearly cross-sectional estimations. To provide an overview, we report the average coefficient, the average marginal effect, and the number of positive, negative, and significant coefficients.

The cross-sectional estimates show a strong institutional preference for investments in firms with governance mechanisms that tend to minimize agency costs. The dummy for whether the CEO is an owner is negative and highly significant. We interpret this result as stemming from the institutional investors' concern about possible expropriation of minority shareholders. This finding is consistent with the evidence in Hellmann and Puri (2002) that VC-backed firms are more likely and faster to replace the founder with an outside CEO. The number of insider directors (board members that are either owners, CEO, or both) enters with a negative and highly significant coefficient in all cross-sectional regressions, whereas the number of outsider directors is positive and significant in all years. This is consistent with the literature on corporate boards (see Hermalin and Weisbach, 2003), as institutional investors prefer to invest in companies with better monitoring of the CEO and the controlling owners (less insider directors) and more likely representation on the board (more outsider directors). Our proxy for private benefits of control is significantly negatively related to institutional investment. Thus, we gain additional evidence consistent with the findings in Giannetti and Simonov (2006) that investors who only enjoy security benefits will tend to avoid investing in companies with high private benefits of control. The dummy for whether the firm voluntarily supplies additional information in the annual report enters with a positive (and significant) coefficient in six (four) out of 8 years. Thus, firms in which institutional investors are owners tend to be more open and transparent than the average closely held firm. The dummy for the more regulated company type, A/S, enters positively and significantly in all years. The regulation of these firms makes expropriation of minority shareholders less likely, since the degrees of freedom for the management or controlling owners generally are reduced. Finally, note that we have omitted control dilution in Model 1 to avoid spurious correlation, since firms with a single owner, by construction, cannot have control dilution or institutional investment. In Model 2, where we restrict the sample to firms with multiple owners, control dilution enters with a positive and highly significant sign in all cross-section regressions. Thus, institutions prefer to invest in companies 
Table III. Definition of explanatory variables and descriptive statistics in 1999

This table lists the definitions of the explanatory variables used throughout the empirical analysis in Section 5. We report the mean (median) of each explanatory variable in 1999 for firms without institutional investments (Firms without II) and firms with institutional investments (Firms with II).

\begin{tabular}{|c|c|c|c|}
\hline \multirow[b]{2}{*}{ Variable } & \multirow[b]{2}{*}{ Definition } & \multicolumn{2}{|c|}{ Mean (median) } \\
\hline & & $\begin{array}{c}\text { Firms } \\
\text { without II }\end{array}$ & $\begin{array}{l}\text { Firms } \\
\text { with II }\end{array}$ \\
\hline \multicolumn{4}{|c|}{ A. Governance mechanisms } \\
\hline Control dilution & $\begin{array}{l}\text { Dummy taking the value } 1 \text { in the absence of a } \\
\text { single controlling owner who possesses more } \\
\text { than } 50 \text { percent of the ownership. Only } \\
\text { reported for the subsample of firms with } \\
\text { multiple owners. }\end{array}$ & $\begin{array}{l}0.191 \\
(0.000)\end{array}$ & $\begin{array}{l}0.702 \\
(1.000)\end{array}$ \\
\hline Insider CEO & $\begin{array}{l}\text { Dummy taking the value } 1 \text { if the } \mathrm{CEO} \text { is an } \\
\text { owner }\end{array}$ & $\begin{array}{l}0.710 \\
(1.000)\end{array}$ & $\begin{array}{l}0.292 \\
(0.000)\end{array}$ \\
\hline Insider directors & $\begin{array}{l}\text { Number of board members that are either } \\
\text { owners or CEO }\end{array}$ & $\begin{array}{l}0.748 \\
(0.000)\end{array}$ & $\begin{array}{l}0.609 \\
(0.000)\end{array}$ \\
\hline Outsider directors & $\begin{array}{l}\text { Number of independent board members, i.e., } \\
\text { the number of board members that neither } \\
\text { are owners nor CEO }\end{array}$ & $\begin{array}{l}1.129 \\
(0.000)\end{array}$ & $\begin{array}{l}4.286 \\
(4.000)\end{array}$ \\
\hline Private benefits & $\begin{array}{l}\text { Dummy taking the value } 1 \text { if the name of a } \\
\text { personal owner is included in the firm name }\end{array}$ & $\begin{array}{l}0.297 \\
(0.000)\end{array}$ & $\begin{array}{l}0.040 \\
(0.000)\end{array}$ \\
\hline Information & $\begin{array}{l}\text { Dummy taking the value } 1 \text { if the firm voluntary } \\
\text { supplies additional accounting information in } \\
\text { the annual report }\end{array}$ & $\begin{array}{l}0.261 \\
(0.000)\end{array}$ & $\begin{array}{l}0.548 \\
(1.000)\end{array}$ \\
\hline Firm type (A/S) & $\begin{array}{l}\text { Dummy taking the value } 1 \text { if the firm is } \\
\text { incorporated under the "A/S" legal form }\end{array}$ & $\begin{array}{l}0.471 \\
(0.000)\end{array}$ & $\begin{array}{l}0.871 \\
(1.000)\end{array}$ \\
\hline \multicolumn{4}{|c|}{ B. Control variables } \\
\hline Assets & $\begin{array}{l}\text { Book value of assets in } 1,000 \text { DKR (log } \\
\text { transformation used in the empirical section) }\end{array}$ & $\begin{array}{l}(14,800.1) \\
(3,273.0)\end{array}$ & $\begin{array}{l}(17,697.5) \\
(32,553.5)\end{array}$ \\
\hline Leverage & Book value of debt over book value of assets & $\begin{array}{l}0.666 \\
(0.694)\end{array}$ & $\begin{array}{l}0.606 \\
(0.621)\end{array}$ \\
\hline Excess RoA & $\begin{array}{l}\text { Operating profit over the book value of assets } \\
\text { minus the two-digit industry median }\end{array}$ & $\begin{array}{l}0.014 \\
(0.008)\end{array}$ & $\begin{array}{l}-0.036 \\
(-0.010)\end{array}$ \\
\hline Industry beta & $\begin{array}{l}\text { Average beta within the two-digit industry } \\
\text { level. Betas for single stocks are estimated } \\
\text { using monthly returns over the preceding } 60 \\
\text { months. For firms in industries without } \\
\text { representation we use the average beta within } \\
\text { the one-digit industry level. }\end{array}$ & $\begin{array}{l}0.899 \\
(0.777)\end{array}$ & $\begin{array}{l}0.971 \\
(1.079)\end{array}$ \\
\hline Industry Q & $\begin{array}{l}\text { Average market-to-book ratio (MB) within the } \\
\text { two-digit industry level. MB is defined as the } \\
\text { market value of equity plus book value of } \\
\text { debt over the book value of assets. For firms } \\
\text { in industries without representation, we use } \\
\text { the average MB within the one-digit industry } \\
\text { level. }\end{array}$ & $\begin{array}{l}1.357 \\
(1.021)\end{array}$ & $\begin{array}{l}1.911 \\
(1.564)\end{array}$ \\
\hline $\begin{array}{l}\text { Number of listed } \\
\text { companies }\end{array}$ & $\begin{array}{l}\text { Number of listed companies on the } \\
\text { Copenhagen Stock Exchange within the } \\
\text { two-digit industry level code }\end{array}$ & $\begin{array}{l}11.52 \\
(2.00)\end{array}$ & $\begin{array}{l}40.37 \\
(11.50)\end{array}$ \\
\hline
\end{tabular}


where no shareholder can take unilateral actions at the expense of other owners.

The evidence on the controls related to other determinants of institutional investment is less clear cut. Firm size enters positively and highly significantly in all eight cross-section regressions, whereas firm age and leverage are insignificant in most years. Institutional investments seem to be negatively and significantly correlated with firm profitability, measured by the excess RoA. Hence, the prudence motive is somewhat blurred.

Table IV also sheds light on whether investments in private equity are driven by diversification and investment opportunities. Industry beta enters with a negative and significant coefficient in 4 years, whereas the remaining four are insignificant with mixed signs. Thus, direct investments in private equity tend to be in low-beta industries. The effect of industry $Q$ on institutional investments is ambiguous, as six (two) out of eight coefficients are positive (negative) of which only three (one) are significant at conventional levels. Surprisingly, the number of listed firms within the industry is positively correlated with the probability of institutional investment. The effect is significant in all eight cross-sectional estimations. Thus, institutions invest in industries that are already represented on the domestic stock exchange.

Table IV also reports the average marginal effect from the eight regressions estimated on cross-sectional data. The marginal effect is the change in the probability of observing an institutional investment for a marginal increase in the explanatory variable. At first glance, the marginal effects might seem very small. However, the size of the marginal effects should be evaluated relative to the distribution of the dependent variable. As shown in Table I, institutional investment is a rare event in the sample. Thus, institutional investors are only present in around 1 percent of the firms. Given the skewed distribution of institutional investments, the marginal effects of governance characteristics on the probability of institutional investment are large. The joint effect of improving all seven governance characteristics is, on average, a 1.26 percent increase in the probability of an institutional investment. ${ }^{26}$

In sum, the evidence is consistent with the view that institutional investors are primarily concerned with agency costs when they invest in private equity. Having considered the determinants of institutional investment in private equity, this begs the question of what determines institutional syndication.

\footnotetext{
${ }^{26}$ We simply sum the marginal effects of having control dilution $(0.34$ percent $)$, an outsider CEO (0.16 percent), one less insider director $(0.12$ percent $)$, one more outsider director $(0.06$ percent), low private benefits of control ( 0.27 percent), an informative annual account ( 0.06 percent) and incorporation under the $\mathrm{A} / \mathrm{S}$ legal form ( 0.25 percent). It is worth noticing that, for each extra outsider director, the marginal effect on the probability of institutional investment increases by 0.06 percent.
} 
Table $I V$. Determinants of institutional investments in private firms

This table reports the determinants of institutional investments in private firms. We estimate the relationship using a logit model where the dependent variable, presence of institutional investors, is a dummy taking the value 1 if an institutional investor is among the owners of the firm. Model 1 uses all firms, whereas Model 2 uses the subsample of firms with multiple owners. Definitions of the explanatory variables and descriptive statistics are provided in Table III. To summarize the eight yearly cross-sectional models, we report the average coefficients, and marginal effects, the number of positive and negative coefficients and the number of significant coefficients at the 5 percent level. Significance is based on White's robust variance estimator.

(1)

Presence of institutional investors

All firms
(2)

Presence of institutional investors Firms with multiple owners
Dependent variable Sample

\begin{tabular}{ccc}
\hline $\begin{array}{c}\text { Average } \\
\text { coefficient }\end{array}$ & $\begin{array}{c}\text { Number of } \\
\text { positive }\end{array}$ & $\begin{array}{c}\text { Number of } \\
\text { negative }\end{array}$ \\
(marginal effect) & (significant) & (significant)
\end{tabular}

$\begin{array}{ccc}\begin{array}{c}\text { Average } \\ \text { coefficient }\end{array} & \begin{array}{c}\text { Number of } \\ \text { positive }\end{array} & \begin{array}{c}\text { Number of } \\ \text { negative }\end{array} \\ \text { (marginal effect) } & \text { (significant) } & \text { (significant) }\end{array}$

\begin{tabular}{|c|c|c|c|c|c|c|}
\hline \multicolumn{7}{|c|}{ A. Governance mechanisms } \\
\hline \multicolumn{4}{|c|}{ Control dilution } & 0.9033 & 8 & 0 \\
\hline \multirow{2}{*}{ Insider CEO } & -0.6221 & 0 & 8 & -0.4588 & 0 & 8 \\
\hline & $(-0.0014)$ & (0) & (8) & $(-0.0016)$ & $(0)$ & (8) \\
\hline \multirow[t]{2}{*}{ Insider directors } & -0.3175 & 0 & 8 & -0.4186 & 0 & 8 \\
\hline & $(-0.0006)$ & (0) & (8) & $(-0.0012)$ & $(0)$ & (8) \\
\hline \multirow[t]{2}{*}{ Outsider directors } & 0.2547 & 8 & 0 & 0.2159 & 8 & 0 \\
\hline & $(0.0004)$ & (8) & (0) & $(0.0006)$ & (8) & (0) \\
\hline \multirow[t]{2}{*}{ Private benefits } & -1.3851 & 0 & 8 & -1.2007 & 0 & 8 \\
\hline & $(-0.0020)$ & (0) & (8) & $(-0.0027)$ & $(0)$ & (8) \\
\hline \multirow[t]{2}{*}{ Information } & 0.3024 & 8 & 0 & 0.2442 & 7 & 1 \\
\hline & $(0.0005)$ & (3) & $(0)$ & $(0.0006)$ & (2) & (0) \\
\hline \multirow[t]{2}{*}{ Firm type (A/S) } & 0.9305 & 8 & 0 & 0.8026 & 8 & 0 \\
\hline & $(0.0020)$ & (8) & (0) & $(0.0025)$ & (8) & (0) \\
\hline \multicolumn{7}{|l|}{ B. Control variables } \\
\hline \multirow{2}{*}{ Assets } & 0.2376 & 8 & 0 & 0.2028 & 8 & 0 \\
\hline & $(0.0004)$ & (8) & $(0)$ & $(0.0006)$ & (8) & (0) \\
\hline \multirow[t]{2}{*}{ Leverage } & -0.1309 & 2 & 6 & -0.1525 & 2 & 6 \\
\hline & $(-0.0002)$ & (1) & (1) & $(-0.0004)$ & (1) & (1) \\
\hline \multirow[t]{2}{*}{ Excess RoA } & -1.3957 & 0 & 8 & -1.1576 & 0 & 8 \\
\hline & $(-0.0024)$ & $(0)$ & (8) & $(-0.0031)$ & $(0)$ & (7) \\
\hline \multirow[t]{2}{*}{ Firm age } & -0.0025 & 2 & 6 & -0.0027 & 3 & 5 \\
\hline & $(-3.3 \mathrm{E}-06)$ & $(0)$ & (0) & $(-5.9 \mathrm{E}-06)$ & $(0)$ & (0) \\
\hline \multirow[t]{2}{*}{ Industry beta } & -0.5854 & 0 & 8 & -0.4528 & 2 & 6 \\
\hline & $(-0.0013)$ & (0) & (5) & $(-0.0017)$ & $(0)$ & (4) \\
\hline \multirow[t]{2}{*}{ Industry Q } & 0.2082 & 6 & 2 & 0.1712 & 6 & 2 \\
\hline & $(0.0006)$ & (3) & (1) & $(0.0009)$ & (3) & (1) \\
\hline \multirow{2}{*}{$\begin{array}{l}\text { Number of listed } \\
\text { companies }\end{array}$} & 0.0490 & 8 & 0 & 0.0451 & 8 & 0 \\
\hline & $(0.0001)$ & (8) & (0) & $(0.0001)$ & (8) & (0) \\
\hline \multirow{2}{*}{\multicolumn{2}{|c|}{$\begin{array}{l}\text { Industry effects } \\
\text { Avg. pseudo- } R^{2}\end{array}$}} & \multirow{2}{*}{\multicolumn{2}{|c|}{$\begin{array}{c}Y E S \\
0.415\end{array}$}} & \multicolumn{3}{|c|}{$Y E S$} \\
\hline & & & & \multicolumn{3}{|c|}{0.418} \\
\hline
\end{tabular}




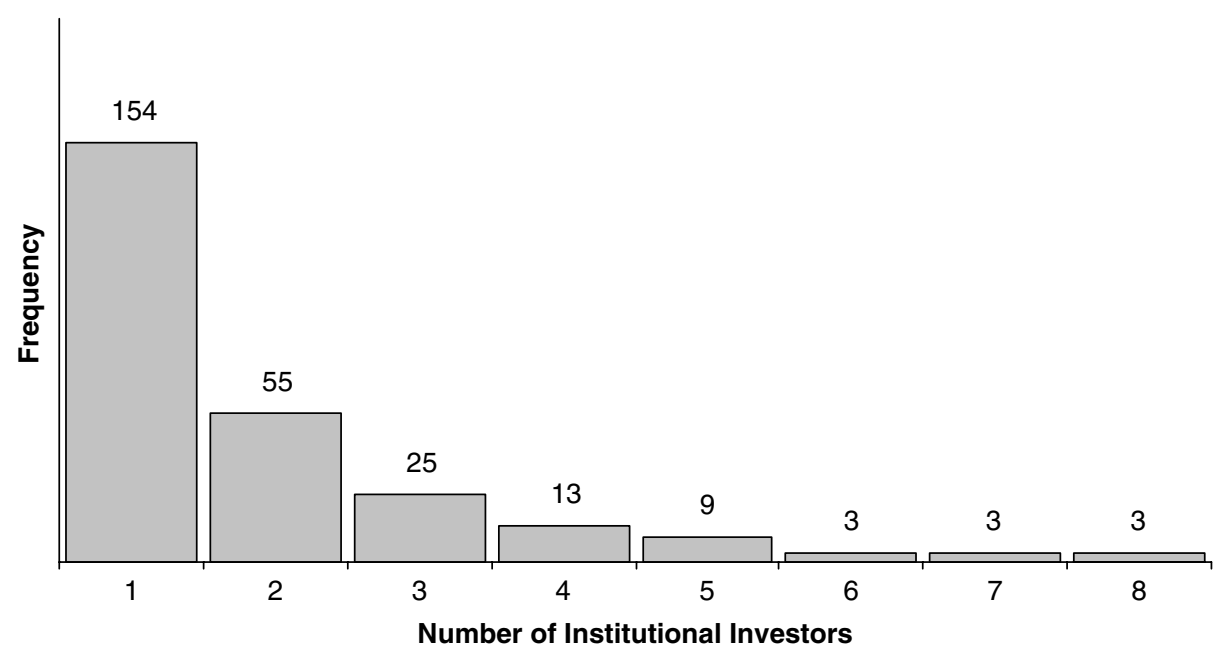

Figure 2. Distribution of the number of institutional investors in the 265 nonfinancial firms with institutional investments in 1999.

\subsection{SYNDICATION OF INSTITUTIONAL INVESTORS}

The previous section analyzed the extent to which institutional investors try to reduce the risk of minority expropriation by selecting companies on the basis of their governance characteristics. In this section, we turn our attention to the situations where institutions syndicate investments, which is another strategy to reduce uncertainty in a high-risk environment. In particular, we are interested in the interaction between the rationale for syndication and the revealed preference for good governance mechanisms.

Syndication through co-investments has been shown to be pronounced in VC and angel financing, with 2 to 10 co-investors per round (see Kaplan and Strömberg, 2003; Wong, 2002). From Table I, it is evident that syndication is less pronounced for institutional investments in private equity, since the average number of institutions in firms with institutional investors among the owners is 1.85. Figure 2 shows the distribution of the number of institutional investors in firms with institutional investment in 1999. In total, institutional investors have invested in 265 firms in 1999. In 111 of these (42 percent), the investment is syndicated with at least two institutions among the owners. In addition, Figure 2 shows that the syndicated investments have few participating institutions. In around 75 percent of the cases, the syndicate consists of two or three institutions. Moreover, in the full sample syndication occurs in 37.7 percent of the firms with institutional investments and in these firms, the average number of institutional investors is 3.15 . 
Previous literature has provided three main rationales for why venture capitalists syndicate investments. First, syndication might lead to superior selection of investments since the project is screened by more investors (Sah and Stiglitz, 1986; Lerner, 1994). A second rationale for syndication is based on the idea that venture capitalists might add value to the ventures in which they invest. Hence, the benefit of syndication is derived from the heterogeneous skills and information different investors can contribute to the management of the firm (Brander et al., 2002). Finally, syndication allows investors to diversify through risk sharing (Wilson, 1968).

In our setting, the risk-sharing motive is directly related to agency costs. From an investment perspective, the exposure to idiosyncratic risk is larger in firms with poor governance mechanisms. This exposure can be reduced through syndication, since syndication allows institutional investors to reduce their individual ownership stake and diversify their investments across more firms and industries. Thus, the potential benefit of syndication is positively related to agency costs. However, syndication might reduce monitoring intensity, as each institution has an incentive to "free ride" on the others (Pichler and Wilhelm, 2001). The implied cost of syndication is, therefore, higher in firms with poor governance mechanisms, since these firms require more monitoring. Thus, from a theoretical perspective, it is an open question whether syndication is a substitute or complement to governance mechanisms. If institutions can effectively share the effort of monitoring we should expect syndication to occur in firms with poor corporate governance. On the other hand, we should expect the opposite if the free riding problem is prevalent, since firms with worse governance mechanisms need more intensive monitoring.

To investigate the role of syndication, we use the subsample of firms with institutional investment. We thereby, focus the analysis on identifying the determinants of syndication, rather than institutional ownership, as in the previous section. We use two specifications. First, we estimate the probability of syndication in a logit model where the dependent variable is an indicator for institutional syndication, which equals 1 if there is more than one institutional investor. Second, we estimate the determinants of the number of institutional investors using an ordered logit model. Again, we summarize the eight yearly cross-section regressions by reporting the average coefficient, the average marginal effect, and the number of positive, negative, and significant coefficients at the 10 percent level. ${ }^{27}$ This is done in Table V.

In both models of syndication, we find a positive effect of good governance mechanisms on the number of institutional investors. However, the effects are

27 We have chosen the 10 percent significance level due to the relatively low number of observations. 
Table $V$. Syndication among institutional investors in firms with institutional investments

This table shows the determinants of institutional syndication. We use two dependent variables: a dummy for institutional syndication, which equals 1 if the number of institutional owners exceeds one and the number of institutional investors and estimate the relationship using a logit and an ordered logit model, respectively. The sample is restricted to firms with at least one institutional investor among the owners. Definitions of the explanatory variables and descriptive statistics are provided in Table III. To summarize the eight yearly cross-section models, we report the average coefficients and marginal effects, the number of positive and negative coefficients and the number of significant coefficients at the 10 percent level. Significance is based on White's robust variance estimator. In Model 2, the marginal effects are reported for the probability of the outcome when the number of institutional investors equals two.

(1)

Institutional syndication Firms with institutional investments
(2)

Number of institutional investors Firms with institutional investments

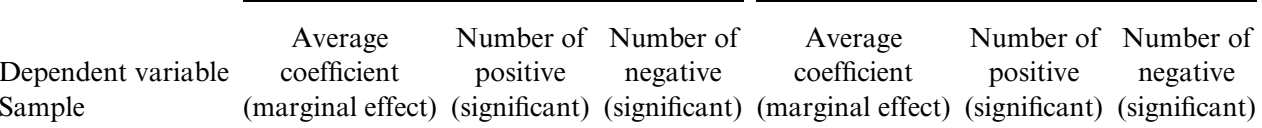

\begin{tabular}{|c|c|c|c|c|c|c|}
\hline \multicolumn{7}{|c|}{ A. Governance mechanisms } \\
\hline \multirow[t]{2}{*}{ Control dilution } & 0.3029 & 7 & 1 & 0.3734 & 8 & 0 \\
\hline & $(0.0746)$ & (2) & (0) & $(0.0426)$ & (4) & (0) \\
\hline \multirow[t]{2}{*}{ Insider CEO } & -0.8263 & 0 & 8 & -0.8493 & 0 & 8 \\
\hline & $(-0.1951)$ & (0) & (7) & $(-0.0928)$ & (0) & (7) \\
\hline \multirow[t]{2}{*}{ Insider directors } & -0.3502 & 1 & 7 & -0.4006 & 0 & 8 \\
\hline & $(-0.0921)$ & (0) & (4) & $(-0.0467)$ & (0) & (6) \\
\hline \multirow[t]{2}{*}{ Outsider directors } & 0.0503 & 6 & 2 & 0.0541 & 7 & 1 \\
\hline & $(0.0116)$ & (2) & (0) & $(0.0059)$ & (2) & (0) \\
\hline \multirow[t]{2}{*}{ Information } & -0.0681 & 5 & 3 & -0.1028 & 5 & 3 \\
\hline & $(-0.0150)$ & (0) & (0) & $(-0.0087)$ & (0) & (0) \\
\hline \multirow[t]{2}{*}{ Firm type (A/S) } & -0.8302 & 0 & 8 & -0.5873 & 0 & 8 \\
\hline & $(-0.2120)$ & (0) & (5) & $(-0.0605)$ & (0) & (4) \\
\hline \multicolumn{7}{|l|}{ B. Control variables } \\
\hline \multirow[t]{2}{*}{ Assets } & 0.1519 & 8 & 0 & 0.1688 & 8 & 0 \\
\hline & $(0.0386)$ & (4) & (0) & $(0.0192)$ & (6) & (0) \\
\hline \multirow[t]{2}{*}{ Leverage } & -0.4697 & 1 & 7 & -0.5766 & 1 & 7 \\
\hline & $(-0.1079)$ & (1) & (2) & $(-0.0617)$ & (1) & (2) \\
\hline \multirow[t]{2}{*}{ Excess RoA } & -0.4240 & 2 & 6 & -0.1481 & 4 & 4 \\
\hline & $(-0.1104)$ & (0) & (0) & $(-0.0209)$ & (0) & (1) \\
\hline \multirow[t]{2}{*}{ Firm age } & -0.0026 & 4 & 4 & -0.0068 & 1 & 7 \\
\hline & $(-0.0005)$ & (0) & (0) & $(-0.0007)$ & (0) & (0) \\
\hline \multirow[t]{2}{*}{ Industry beta } & -0.1913 & 4 & 4 & -0.2330 & 3 & 5 \\
\hline & $(-0.0419)$ & (0) & (1) & $(-0.0248)$ & (0) & (1) \\
\hline \multirow[t]{2}{*}{ Industry Q } & -0.2367 & 4 & 4 & -0.2501 & 4 & 4 \\
\hline & $(-0.0702)$ & (0) & (2) & $(-0.0381)$ & (0) & (2) \\
\hline \multirow{2}{*}{$\begin{array}{l}\text { Number of listed } \\
\text { companies }\end{array}$} & 0.0088 & 8 & 0 & 0.0079 & 8 & 0 \\
\hline & $(0.0027)$ & (5) & (0) & $(0.0011)$ & (5) & (0) \\
\hline Industry effects & & YES & & & YES & \\
\hline Avg. Pseudo- $R^{2}$ & & 0.182 & & & 0.118 & \\
\hline
\end{tabular}


generally less significant than in the regression of institutional ownership in Table IV. In part, this is due to the relatively low number of observations, and in part, to the limited variation in the explanatory variables in the subsample of firms with institutional owners. For instance, Table III reveals that, on average, only 4 percent of the firms have an overlap between the family and firm name (private benefits). None of the firms with institutional investment in 1996 and 1997 has high private benefits of control. We have, therefore, been forced to drop private benefits from the analysis of institutional syndication. Thus, whereas governance mechanisms that tend to reduce the agency costs are positively correlated with institutional ownership in general, their explanatory power as determinants of institutional syndication is weaker. In addition, few of our controls for other preferences appear significant: syndication tends to occur in large firms with low leverage that operate in industries that are represented on the local stock exchange.

In summary, firms in which institutions have made syndicated investments seem to have slightly better governance mechanisms than firms with a single institutional investor. Our results show that companies with good governance characteristics tend to feature not only investments by institutional investors, but also more frequent presence of syndication. This suggests that agency problems are prevalent in private firms, since institutions enjoy the benefits of portfolio diversification only in firms with good governance mechanisms.

The potential endogeneity of the companies' governance characteristics is a concern when interpreting the results of Tables IV and V: so far, we have assumed these characteristics to drive both the investment and syndication choices of institutional investors. But in fact, these choices may, in turn, affect the firms' governance characteristics. We now turn our attention to this important issue.

\subsection{INSTITUTIONAL INVESTORS AMONG NEW OWNERS}

Using the panel structure of the data, we identify a subsample of firms that changed their ownership structure. In particular, we identify a subsample of 13,664 firms where new owners were introduced. Among the new owners, we identify the institutional investors. We thereby obtain a sufficiently large sample to analyze changes in ownership over time.

Table VI reports the distribution of firms that introduce new owners across years and industries. The average number of new owners is around 2, and 692 out of the 13,664 firms (5.1 percent) introduced at least one institutional investor among the new owners. Furthermore, Table VI reveals that in these 692 firms, the average number of institutions among new owners is 3.2. There 
Table VI. Introduction of new owners in private firms, 1996-2003

This table shows the number of firms that introduce a new owner within the period 1996-2003. All firms w/ ownership change is all privately held limited liability companies in Denmark with an ownership change that introduces new owners, whereas firms with ownership change and institutions among new owners is the subset of firms that introduces a new owner and where at least one is an institutional investor. We report the number of firms with an ownership change (Number of firms), the share of all firms and the average number of new owners and institutions, respectively. Panel A reports the introduction of new owners per year, whereas Panel B shows the introduction of new owners by industry for all years.

\begin{tabular}{|c|c|c|c|c|c|c|}
\hline & \multicolumn{3}{|c|}{ All firms w/ ownership change } & \multicolumn{3}{|c|}{$\begin{array}{l}\text { Firms w/ ownership change and } \\
\text { institutions among the new owners }\end{array}$} \\
\hline & $\begin{array}{l}\text { Number } \\
\text { of firms }\end{array}$ & $\begin{array}{l}\text { Share of all } \\
\text { firms }(\%)\end{array}$ & $\begin{array}{c}\text { Average } \\
\text { number of } \\
\text { new owners }\end{array}$ & $\begin{array}{l}\text { Number } \\
\text { of firms }\end{array}$ & $\begin{array}{l}\text { Share of all } \\
\text { firms with } \\
\text { ownership } \\
\text { change (\%) }\end{array}$ & $\begin{array}{c}\text { Average } \\
\text { number of } \\
\text { institutions }\end{array}$ \\
\hline \multicolumn{7}{|c|}{ A: Introduction of new owners by year } \\
\hline 1996 to 1997 & 1,879 & 7.0 & 1.89 & 98 & 5.2 & 2.92 \\
\hline 1997 to 1998 & 2,278 & 8.1 & 1.89 & 113 & 5.0 & 3.14 \\
\hline 1998 to 1999 & 2,391 & 8.5 & 2.01 & 134 & 5.6 & 3.69 \\
\hline 1999 to 2000 & 2,200 & 7.7 & 2.03 & 144 & 6.5 & 2.18 \\
\hline 2000 to 2001 & 2,098 & 7.6 & 2.09 & 122 & 5.8 & 3.61 \\
\hline 2001 to 2002 & 1,256 & 4.4 & 2.02 & 42 & 3.4 & 4.62 \\
\hline 2002 to 2003 & 1,562 & 5.3 & 1.79 & 39 & 2.5 & 3.87 \\
\hline All & 13,664 & 6.9 & 1.97 & 692 & 5.1 & 3.23 \\
\hline \multicolumn{7}{|c|}{ B: Introduction of new owners by industry } \\
\hline Communications & 121 & 12.0 & 2.31 & 16 & 13.2 & 2.25 \\
\hline Computer related & 510 & 11.1 & 2.70 & 62 & 12.2 & 3.71 \\
\hline Other electronics & 166 & 10.0 & 2.43 & 14 & 8.4 & 3.57 \\
\hline Research \& development & 95 & 31.0 & 7.91 & 42 & 44.2 & 5.07 \\
\hline Medical \& health related & 70 & 8.7 & 3.79 & 13 & 18.6 & 5.85 \\
\hline Energy & 13 & 10.0 & 3.31 & 2 & 15.4 & 2.00 \\
\hline Consumer products & 5,116 & 7.3 & 1.72 & 156 & 3.1 & 2.88 \\
\hline Industrial products & 1,465 & 9.8 & 2.37 & 109 & 7.5 & 3.86 \\
\hline Transportation & 694 & 6.9 & 1.86 & 13 & 1.9 & 1.23 \\
\hline Other industries & 5,414 & 6.3 & 1.88 & 265 & 4.9 & 2.79 \\
\hline All & 13,664 & 6.9 & 1.97 & 692 & 5.1 & 3.23 \\
\hline
\end{tabular}

are significant differences across industries. Whereas the ownership changes are fairly uniformly distributed across industries, the frequency of institutional investments is higher in firms operating within information technology, research and development, and medical and health related industries.

We make use of both, the dummy for the presence of an institutional investor (Model 1), and the indicator for institutional syndication (Model 3 ) as dependent variables in the full sample and subsample of firms with 
institutional investments, respectively. In Model 2, we exclude firms in which another institutional investor was already an owner.

To induce causality, we regress the dependent variables on lagged explanatory variables. Thus, by construction, we limit the possibility of reverse causality where the governance characteristics are determined by the presence of an institutional investor. ${ }^{28}$ The results are reported in Table VII.

Table VII shows a strong significantly positive effect of governance mechanisms on the probability of institutional investment. Given that the unconditional probability of observing institutional investment is 5.1 percent, the marginal effects of improving the governance characteristics are large. Firms with control dilution have a 3.1 percent higher probability of institutional investment. The marginal effect of private benefits of control (overlap between the family and firm name) reduces the probability by 1.7 percent. This confirms that institutional investors fear expropriation and invest in firms with governance mechanisms that reduce this risk. We obtain similar results in Model 2, when we exclude firms in which another institutional investor was already an owner. Interestingly, in both models we find evidence of institutional ownership being more likely in low-beta and high-Q industries that are well represented on the stock exchange.

In Model 3, we confirm the previous insight that institutional syndication is positively related to good governance mechanisms. Institutional syndication is more likely in firms where the CEO is an outsider and in firms with outside board members. Thus, good governance mechanisms allow institutions to enjoy the benefits of syndication and thereby reduce the idiosyncratic risk.

\subsection{EFFECTS OF INSTITUTIONAL OWNERSHIP ON THE GOVERNANCE CHAR- ACTERISTICS AND PERFORMANCE OF PRIVATE FIRMS}

In the previous section, we demonstrated that the governance characteristics of private firms affect the investment choices of institutional investors. But this does not necessarily rule out the possibility that, to a certain extent, institutional ownership may feed back on companies' governance quality and performance. We investigate this point by relying on the subsample of 692 firms that introduced an institution among the owners and focus on identifying the effect on governance mechanisms, operating performance, and growth. ${ }^{29}$

\footnotetext{
28 To further reduce this possibility, we can increase the time separation between observing firm characteristics and institutional investment beyond 1 year. We obtain identical results when we do this, even though the number of observations is reduced.

29 Again, we report the results for all firms with an institutional investor among the new owners and for the subsample of these with no institution among the initial owners. However, as the results are very similar, we only comment on the results in the full sample.
} 
Table VII. Determinants of institutional investors among new owners

This table reports the determinants of institutional investors among new owners. In Model 1 and 2, we estimate the relationship using a logit model where the dependent variable, presence of institutional investors, is a dummy taking the value 1 if an institutional investor is among the owners of the firm. In Model 3, the dependent variable is an indicator for institutional syndication, which takes the value 1 if the number of institutional owners exceeds one. Model 1 uses all firms with new owners, whereas Model 2 excludes firms where another institution was among the initial owners. Model 3 uses the subsample of firms with institutions among the new owners. T-statistics based on robust standard errors are reported in parentheses.

\begin{tabular}{|c|c|c|c|c|c|c|}
\hline \multirow[b]{3}{*}{$\begin{array}{l}\text { Dependent variable } \\
\text { Sample }\end{array}$} & \multicolumn{2}{|c|}{$\begin{array}{c}(1) \\
\text { Presence of } \\
\text { institutional investors }\end{array}$} & \multirow{2}{*}{\multicolumn{2}{|c|}{$\begin{array}{c}\text { (2) } \\
\text { Presence of institutional } \\
\text { investors } \\
\begin{array}{c}\text { Firms w/ new owners } \\
\text { and no institution among } \\
\text { the initial owners }\end{array}\end{array}$}} & \multicolumn{2}{|c|}{$\begin{array}{c}\text { (3) } \\
\text { Institutional } \\
\text { syndication }\end{array}$} \\
\hline & \multicolumn{2}{|c|}{ Firms w/ new owners } & & & \multicolumn{2}{|c|}{$\begin{array}{l}\text { Firms w/ institutions } \\
\text { among new owners }\end{array}$} \\
\hline & Coefficient & $\begin{array}{c}\text { Marginal } \\
\text { effect }\end{array}$ & Coefficient & $\begin{array}{c}\text { Marginal } \\
\text { effect }\end{array}$ & Coefficient & $\begin{array}{c}\text { Marginal } \\
\text { effect }\end{array}$ \\
\hline \multicolumn{7}{|c|}{ A. Governance mechanisms } \\
\hline Control dilution & $\begin{array}{l}1.2210^{* * *} \\
(12.7)\end{array}$ & 0.0311 & $\begin{array}{c}1.1272^{* * *} \\
(10.5)\end{array}$ & 0.0227 & $\begin{array}{c}0.2430 \\
(1.17)\end{array}$ & 0.0511 \\
\hline Insider CEO & $\begin{array}{c}-0.1210 \\
(-1.27)\end{array}$ & -0.0024 & $\begin{array}{c}0.0344 \\
(0.32)\end{array}$ & 0.0005 & $\begin{array}{c}-0.6590^{* * *} \\
(-3.22)\end{array}$ & -0.1399 \\
\hline Insider directors & $\begin{array}{c}-0.5106^{* * *} \\
(-8.45)\end{array}$ & -0.0102 & $\begin{array}{c}-0.4324^{* * *} \\
(-6.35)\end{array}$ & -0.0068 & $\begin{array}{l}-0.1425 \\
(-1.18)\end{array}$ & -0.0294 \\
\hline Outsider directors & $\begin{array}{c}0.1059^{* * *} \\
(4.30)\end{array}$ & 0.0021 & $\begin{array}{c}0.0941^{* * *} \\
(3.09)\end{array}$ & 0.0015 & $\begin{array}{c}0.1088^{*} \\
(1.75)\end{array}$ & 0.0224 \\
\hline Private benefits & $\begin{array}{c}-1.1187^{* * *} \\
(-6.08)\end{array}$ & -0.0171 & $\begin{array}{c}-1.0771^{* * *} \\
(-5.35)\end{array}$ & -0.0132 & $\begin{array}{c}-0.8266^{* *} \\
(-2.16)\end{array}$ & -0.1910 \\
\hline Information & $\begin{array}{l}0.2770^{* * *} \\
(2.92)\end{array}$ & 0.0059 & $\begin{array}{l}0.3921^{* * * *} \\
(3.56)\end{array}$ & 0.0068 & $\begin{array}{l}-0.0179 \\
(-0.09)\end{array}$ & -0.0037 \\
\hline Firm type (A/S) & $\begin{array}{l}1.3692^{* * *} \\
(8.53)\end{array}$ & 0.0245 & $\begin{array}{l}1.3534^{* * * *} \\
(7.53)\end{array}$ & 0.0194 & $\begin{array}{c}-0.7441^{* *} \\
(-2.03)\end{array}$ & -0.1319 \\
\hline \multicolumn{7}{|l|}{ B. Control variables } \\
\hline Assets & $\begin{array}{c}0.2002^{* * *} \\
(6.48)\end{array}$ & 0.0040 & $\begin{array}{c}0.1768^{* * * *} \\
(4.64)\end{array}$ & 0.0028 & $\begin{array}{c}0.0829 \\
(1.24)\end{array}$ & 0.0171 \\
\hline Leverage & $\begin{array}{c}-0.1200^{*} \\
(-1.68)\end{array}$ & -0.0024 & $\begin{array}{l}-0.0511 \\
(-0.72)\end{array}$ & -0.0008 & $\begin{array}{l}-0.1329 \\
(-1.02)\end{array}$ & -0.0274 \\
\hline Excess RoA & $\begin{array}{c}-1.4730^{* * *} \\
(-8.10)\end{array}$ & -0.0293 & $\begin{aligned}-1.4752^{* * *} \\
(-6.83)\end{aligned}$ & -0.0231 & $\begin{array}{l}-0.1481 \\
(-0.38)\end{array}$ & -0.0305 \\
\hline Firm age & $\begin{array}{c}-0.0094^{* * *} \\
(-3.21)\end{array}$ & -0.0002 & $\begin{array}{c}-0.0086^{* * *} \\
(2.42)\end{array}$ & -0.0001 & $\begin{array}{l}-0.0064 \\
(-1.06)\end{array}$ & -0.0013 \\
\hline Industry beta & $\begin{array}{l}-0.1975 \\
(-1.56)\end{array}$ & -0.0039 & $\begin{array}{c}-0.3847^{* * *} \\
(-2.68)\end{array}$ & -0.0060 & $\begin{array}{l}-0.5783^{*} \\
(-1.95)\end{array}$ & -0.1192 \\
\hline Industry Q & $\begin{array}{l}0.1560^{* * *} \\
\quad(3.13)\end{array}$ & 0.0031 & $\begin{array}{c}0.1260^{* *} \\
(2.18)\end{array}$ & 0.0020 & $\begin{array}{c}0.0209 \\
(0.16)\end{array}$ & 0.0043 \\
\hline $\begin{array}{l}\text { Number of listed } \\
\text { companies }\end{array}$ & $\begin{array}{l}0.0092^{* * *} \\
\quad(4.81)\end{array}$ & 0.0002 & $\begin{array}{l}0.0040 \\
(1.33)\end{array}$ & 0.0001 & $\begin{array}{c}0.0061^{*} \\
(1.66)\end{array}$ & 0.0013 \\
\hline Industry effects & \multicolumn{2}{|c|}{ YES } & \multicolumn{2}{|c|}{ YES } & \multicolumn{2}{|c|}{ YES } \\
\hline Year effects & \multirow{2}{*}{\multicolumn{2}{|c|}{$\begin{array}{c}\text { YES } \\
0.246\end{array}$}} & \multirow{2}{*}{\multicolumn{2}{|c|}{ YES }} & \multicolumn{2}{|c|}{ YES } \\
\hline Pseudo- $R^{2}$ & & & \multirow{2}{*}{\multicolumn{2}{|c|}{$\begin{array}{c}0.185 \\
13,165\end{array}$}} & \multirow{2}{*}{\multicolumn{2}{|c|}{$\begin{array}{c}0.099 \\
692\end{array}$}} \\
\hline $\mathrm{N}$ & \multicolumn{2}{|c|}{13,664} & & & & \\
\hline
\end{tabular}

$* * *, * *$ and ${ }^{*}$ denote significance at the 1,5 and 10 percent levels, respectively. 
Panel A in Table VIII reports the average governance characteristics 1 year before and 1 year after the introduction of an institutional investor. Consistent with an institutional preference for good governance mechanisms, we find that these tend to improve after the introduction of an institutional investor: the fraction of firms with an outside CEO increases by 9 percentage points. This difference is significant at the 1 percent level. The composition of the board is approximately constant. The number of insider directors decreases slightly and that of outsider directors increases slightly, but both changes are not statistically significant. Our measure of the private benefits of control declines significantly, although this change is driven primarily by the exit of family owners. Finally, there is a significant increase of 5 percentage points in the fraction of firms that supplies additional information in the annual account subsequent to an investment by an institutional investor. Thus, not only are institutions attracted to companies with good governance mechanisms, but they also tend to improve these mechanisms after investing in them. Interestingly, the magnitude of our results shows that the selection of firms with good minority protection dominates.

Panel B in Table VIII shows the link between institutional ownership and performance measured by the industry-adjusted operating RoA. We report the performance before and after the introduction of an institutional owner on a 1- and 3-year horizon, respectively. We find that institutions invest in companies that underperform the median firm within the industry both before and after the change in ownership. Indeed, there is a small decline in the relative performance subsequent to an investment, although this effect is significant only when we use the average performance 3 years before and after the change. One explanation to this underperformance might be that institutions selectively invest in companies that need funding to finance growth. We pursue this question in Panel C in Table VIII, where we report industryadjusted growth in assets and number of employees before and after the ownership change. Firms with institutional investors have both economically and statistically higher growth than the median firm within the industry both before and after the change. In the 3 years preceding the investment, the "excess" growth in assets (employees) is 105.4 percent (30.3 percent), which corresponds to an average yearly growth of 27.1 percent (9.2 percent). Subsequent to the introduction of institutional owners, the excess growth in assets declines significantly to 11.2 and 19.2 percent on a 1 - and 3-year horizon, respectively. Thus, the large growth in assets seems to explain the documented underperformance in RoA. We observe a similar decline in the excess growth in number of employees after the change. Therefore, the evidence indicates 
Table VIII. Effects of institutional ownership on governance and performance

This table shows the effect of institutional ownership on (a) governance mechanisms, (b) operating performance and (c) growth. The sample consists of firms that introduced a new institutional investor as owner within the period 1996-2003 and the subsample of these where there was no institution among the initial owners (see descriptive statistics in Table VI). We report the characteristics of the average firm before and after the institution invested in the firm. Panel A focuses on the governance mechanisms used in the preceding analysis (see Table III for definitions). Panel B reports the average industry-adjusted operating RoA, whereas Panel $\mathrm{C}$ shows the average industry-adjusted growth in the book value of assets and number of employees. We measure performance and growth rates using both a 1-year and 3-year horizon and industry-adjust using the median on the two-digit industry level. In all Panels, we test whether the differences in characteristics and outcomes before and after the introduction of institutional investors are significant using a standard $t$-test. In Panel B and C we also test whether the industry-adjusted performance and growth before and after the ownership change is significantly different from 0 . T-statistics for these tests are reported in parenthesis.

\begin{tabular}{|c|c|c|c|c|c|c|}
\hline \multirow[b]{2}{*}{ Sample } & \multicolumn{3}{|c|}{$\begin{array}{l}\text { Institutional investor } \\
\text { among new owners }\end{array}$} & \multicolumn{3}{|c|}{$\begin{array}{c}\text { Institutional investor among new } \\
\text { owners and no institution among } \\
\text { the initial owners }\end{array}$} \\
\hline & Before & After & Difference & Before & After & Difference \\
\hline \multicolumn{7}{|l|}{ A. Governance mechanisms } \\
\hline Control dilution & 0.719 & 0.708 & $\begin{array}{l}-0.010 \\
(-0.57)\end{array}$ & 0.648 & 0.660 & $\begin{array}{l}0.010 \\
(0.42)\end{array}$ \\
\hline Insider CEO & 0.382 & 0.292 & $\begin{array}{c}-0.090^{* * *} \\
(-5.56)\end{array}$ & 0.456 & 0.343 & $\begin{array}{c}-0.113^{* * *} \\
(-5.38)\end{array}$ \\
\hline Insider directors & 0.738 & 0.696 & $\begin{array}{l}-0.042 \\
(-1.43)\end{array}$ & 0.889 & 0.829 & $\begin{array}{l}-0.060 \\
(-1.57)\end{array}$ \\
\hline Outsider directors & 3.873 & 3.880 & $\begin{array}{l}0.007 \\
(0.13)\end{array}$ & 3.350 & 3.406 & $\begin{array}{l}0.055 \\
(0.90)\end{array}$ \\
\hline Private benefits & 0.050 & 0.036 & $\begin{array}{c}-0.014^{* *} \\
(-2.00)\end{array}$ & 0.063 & 0.043 & $\begin{array}{c}-0.020^{* *} \\
(-2.01)\end{array}$ \\
\hline Information & 0.470 & 0.524 & $\begin{array}{c}0.054^{* * *} \\
(3.14)\end{array}$ & 0.426 & 0.496 & $\begin{array}{c}0.071^{* * *} \\
(3.34)\end{array}$ \\
\hline \multicolumn{7}{|c|}{ B. Industry-adjustedoperating performance } \\
\hline Return on assets (1 year) & $\begin{array}{c}-0.052^{* * *} \\
(-5.22)\end{array}$ & $\begin{array}{c}-0.069^{* * *} \\
(-5.99)\end{array}$ & $\begin{array}{l}-0.017 \\
(-1.49)\end{array}$ & $\begin{array}{c}-0.054^{* * *} \\
(-5.10)\end{array}$ & $\begin{array}{c}-0.067^{* * *} \\
(-5.34)\end{array}$ & $\begin{array}{l}-0.013 \\
(-0.95)\end{array}$ \\
\hline Return on assets ( 3 year) & $\begin{array}{c}-0.041^{* * *} \\
(-5.12)\end{array}$ & $\begin{array}{c}-0.066^{* * *} \\
(-6.20)\end{array}$ & $\begin{array}{l}-0.025^{*} \\
(-2.36)\end{array}$ & $\begin{array}{l}-0.046^{* * *} \\
(-4.97)\end{array}$ & $\begin{array}{c}-0.066^{* * *} \\
(-5.65)\end{array}$ & $\begin{array}{l}-0.020^{*} \\
(-1.69)\end{array}$ \\
\hline \multicolumn{7}{|l|}{ C. Industry-adjusted growth } \\
\hline Growth in assets (1 year) & $\begin{array}{c}0.229^{* * *} \\
(5.74)\end{array}$ & $\begin{array}{c}0.112^{* * *} \\
(2.80)\end{array}$ & $\begin{array}{c}-0.117^{* *} \\
(-2.05)\end{array}$ & $\begin{array}{c}0.220^{* * *} \\
(5.20)\end{array}$ & $\begin{array}{l}0.112^{* *} \\
(2.59)\end{array}$ & $\begin{array}{l}-0.107^{*} \\
(-1.75)\end{array}$ \\
\hline Growth in assets ( 3 year) & $\begin{array}{c}1.054^{* * *} \\
(8.64)\end{array}$ & $\begin{array}{c}0.197^{* * * *} \\
(2.16)\end{array}$ & $\begin{array}{l}-0.858^{* * *} \\
(-5.23)\end{array}$ & $\begin{array}{c}1.001^{* * * *} \\
(7.71)\end{array}$ & $\begin{array}{c}0.187^{* *} \\
(1.92)\end{array}$ & $\begin{array}{c}-0.814^{* * *} \\
(-4.62)\end{array}$ \\
\hline Growth in employment (1 year) & $\begin{array}{c}0.091^{* * *} \\
(4.55)\end{array}$ & $\begin{array}{l}0.054^{*} \\
(1.89)\end{array}$ & $\begin{array}{l}-0.038 \\
(-0.86)\end{array}$ & $\begin{array}{c}0.088^{* * *} \\
(4.35)\end{array}$ & $\begin{array}{l}0.077^{*} \\
(1.70)\end{array}$ & $\begin{array}{l}-0.011 \\
(-0.22)\end{array}$ \\
\hline Growth in employment (3 year) & $\begin{array}{c}0.303^{* * *} \\
(7.21)\end{array}$ & $\begin{array}{l}0.094^{*} \\
(1.72)\end{array}$ & $\begin{array}{c}-0.210^{* * *} \\
(-3.03)\end{array}$ & $\begin{array}{c}0.320^{* * *} \\
(6.68)\end{array}$ & $\begin{array}{l}0.102 \\
(1.45)\end{array}$ & $\begin{array}{c}-0.218^{* * *} \\
(-2.76)\end{array}$ \\
\hline
\end{tabular}

${ }^{* * *},{ }^{* *}$ and ${ }^{*}$ denote significance at the 1,5 and 10 percent levels, respectively. 
that high-growth firms tend to attract investments from institutional investors with deep pockets to finance future growth. ${ }^{30}$

\subsection{ROBUSTNESS}

In this section, we briefly summarize a number of robustness checks to the preceding analysis. ${ }^{31}$ Institutional investors include banks, insurance companies, and pension funds. From the literature on banking we know that, due to relation-specific lending, banks have access to valuable information for small firms, in particular (see Petersen and Rajan, 1994; Berger and Udell, 1995; a.o.). This suggests that investments in private equity made by banks might be different from those made by other institutions, such as pension funds. Even though our data cannot shed light on whether private equity investments by banks are relation-specific or not, this raises the concern that banks' private equity investments (which account for around one-third of the investments) might be driven by an important omitted variable. Therefore, as a robustness check, we examine the determinants of pension funds' investments in private equity, since pension funds have limited access to relation-specific information. The results that we obtain by restricting the dependent variable to investments by pension funds only are similar to those that we obtain from the entire sample.

Another valid concern with the previous analysis is that we use the population of privately held firms, whereas institutional investors might only consider investing in firms above a certain size threshold. If governance mechanisms are a function of firm size, this selection bias will erroneously attribute the characteristics of large firms to the set of firms preferred by institutional investors. To shed light on this problem, we replicate the empirical analysis using two subsamples where we only include firms with assets above the median and 75th percentile, respectively. The estimates obtained for both subsamples indicate that the effects of governance mechanisms on institutional ownership are both economically and statistically similar to those obtained using the full sample. Firm size and governance quality are weakly correlated in our sample: the correlation coefficients between firm size (assets) and the seven governance mechanisms vary between -0.05 and 0.13 . We therefore, conclude that our results are unlikely to be driven by potential selection bias related to firm size.

\footnotetext{
${ }^{30}$ In addition, this suggests that the equity infusion by institutional investors may be partly used to rebalance the firms' capital structure. In fact, the change in the capital structure measured by the book equity ratio (unreported) is small and insignificant, which suggest that the growth is financed by both equity and debt.

31 All robustness checks are available by request.
} 
In our specification, we controlled for risk by including the industrylevel beta, calculated from data for stocks listed on the Copenhagen Stock Exchange. Ideally, our risk measure should capture individual company risk, since companies might have different risk loadings to market factors when compared to the average firm within the industry. However, the combination of a limited time series and a relatively large number of start-up companies makes it impossible to control for individual company risk for the population of private firms. To check the robustness of this omission we have, in unreported regressions, included the 3-year variance on operating RoA as an additional control variable. The volatility measure is insignificant in all specification and appears to have little effect on our results. In fact, the volatility of RoA is weakly correlated with our seven governance mechanisms. ${ }^{32}$ Thus, our results are unchanged when we include measures that proxy for individual company risk.

Finally, we perform an additional robustness check to address the concern that institutional investors' ownership of private equity is a rare event (only 1 percent of the firms have an institutional owner). This concern is particularly valid when one uses logistic regression on data of rare events, since the logit model tends to underestimate the probability of the event in finite samples. We use a method developed within political and social sciences by King and Zeng (2001) to study rare events such as wars, decisions of citizens to run for political office, or infections by uncommon diseases. When we correct the estimates for the rare event bias using the statistical procedure of King and Zeng (2001), the effect on the estimated coefficients is very small. Thus, the results are not an artifact of a rare event bias.

\section{Conclusion}

Motivated by the novel finding that institutional investors also invest directly in private equity, this paper investigates the determinants of institutional investments in privately held corporations.

We find that institutional investors invest in firms with governance mechanisms that tend to minimize the risk of expropriation by controlling shareholders. Good governance mechanisms further allow institutional investors to cluster into syndicates and thereby enjoy the benefit of portfolio diversification. These findings are robust in controlling for the endogeneity of investment preferences and rare-event bias. In addition, we show that direct investments in private equity tend to be followed by further improvements in

32 The correlation coefficients between the 3-year variance on the operating performance and the seven governance mechanisms vary between -0.002 and 0.026 . 
corporate governance and tend to occur in high-growth firms within research and development-intensive industries. Interestingly, these firms appear to have characteristics that are similar to firms that receive $\mathrm{VC}$ financing.

Since institutional investors can invest in private equity either directly or indirectly through funds, our findings raise two interesting question for future research: What determines which of the two channels they choose in each circumstance? And do institutional investors play a more active role in firms where they have invested directly? Answering these questions might be very important in improving understanding of the role and scope of entrepreneurial financing across industries and countries.

\section{References}

Bennedsen, M., Fosgerau, M. and Nielsen, K. M. (2003) The Strategic Choice of Control Allocation and Ownership Distribution in Closely Held Corporations, unpublished working paper, Copenhagen Business School.

Bennedsen, M. and Wolfenzon, D. (2000) The balance of power in closely held corporations, Journal of Financial Economics 58, 113-139.

Bennett, J. A., Sias, R. W. and Starks, L. T. (2003) Greener pastures and the impact of dynamic institutional preferences, The Review of Financial Studies 16, 1203-1238.

Berger, A. N. and Udell, G. F. (1995) Relationship lending and lines of credit in small firm finance, Journal of Business 68, 351-382.

Bottazzi, L. and Da Rin, M. (2002) Venture capital in Europe and the financing of innovative companies, Economic Policy 34, 229-262.

Brander, J. A., Amit, R. and Antweiler, W. (2002) Venture capital syndication: improved venture selection versus the value-added hypotheses, Journal of Economics and Management Strategy 11, 423-451.

Cumming, D. and Johan, S. (2007) Regulatory harmonization and the development of private equity markets, Forthcoming in Journal of Banking and Finance.

Dahlquist, M. and Robertsson, G. (2001) Direct foreign ownership, institutional investors, and firm characteristics, Journal of Financial Economics 59, 413-440.

Del Guercio, D. (1996) The distorting effect of the prudent-man laws on institutional equity investments, Journal of Financial Economics 40, 31-62.

Demsetz, H. and Lehn, K. (1985) The structure of corporate ownership: Causes and consequences, Journal of Political Economy 93, 1155-1177.

Denis, D. J. (2004) Entrepreneurial finance: an overview of the issues and evidence, Journal of Corporate Finance 10, 301-326.

Dyck, A. and Zingales, L. (2004) Private benefits of control: an international comparison, The Journal of Finance 59, 537-600.

Easterbrook, F. H. and Fischel, D. R. (1986) Close corporations and agency costs, Stanford Law Review 38, 271-301.

Ehrhardt, O. and Nowak, E. (2003) Private Benefits and Expropriation of Minority Shareholders, unpublished working paper, Humboldt University, University of Lugano.

Fenn, G. W., Liang, N. and Prowse, S. (1997) The private equity market: An overview, Financial Markets, Institutions, and Instruments 6, 1-106. 
Giannetti, M. and Simonov, A. (2006) Which investors fear expropriation? Evidence form investors' portfolio choices, The Journal of Finance 61, 1506-1547.

Gomes, A. R. and Novaes, W. (2005) Sharing of Control Versus Monitoring as Corporate Governance Mechanisms, unpublished working Paper, University of Pennsylvania, Pontifical Catholic University of Rio de Janeiro.

Gompers, P. A. and Lerner, J. (2000a) The Venture Capital Cycle, The MIT Press, Cambridge, Massachusetts.

Gompers, P. A. and Lerner, J. (2000b.) The determinants of corporate venture capital success: Organizational structure, incentives and complementarities, in: R. Morck (ed.), Concentrated Corporate Ownership, University of Chicago Press, Chicago, pp. 17-50.

Gompers, P. A. and Lerner, J. (2001) The venture capital revolution, Journal of Economic Perspectives 15, 145-168.

Gompers, P. A. and Metrick, A. (2001) Institutional investors and equity prices, The Quarterly Journal of Economics 116, 229-259.

Hellmann, T. F. (1998) A Theory of Corporate Venture Investing, unpublished working paper, Stanford University.

Hellmann, T. F. and Puri, M. (2002) Venture capital and the professionalization of start-up firms: empirical evidence, The Journal of Finance 57, 169-197.

Hermalin, B. E. and Weisbach, M. S. (2003) Boards of directors as an endogenously determined institution: A survey of the economic literature, Federal Reserve Bank of New York-Economic Policy Review 9, 7-26.

Hwang, M., Quigley, J. M. and Woodward, S. M. (2005) An index for venture capital, 1987-2003, Contributions to Economic Analysis and Policy 4, 1-43.

Jensen, M. C. and Meckling, W. H. (1976) Theory of the firm: managerial behavior, agency costs and ownership structure, Journal of Financial Economics 3, 303-360.

Johnson, S., La Porta, R., Lopez-de-Silanes, F. and Shleifer, A. (2000) Tunneling, American Economic Review Papers and Proceedings 90, 22-27.

Kaplan, S. N. and Strömberg, P. (2003) Financial contracting theory meets the real world: An empirical analysis of venture capital contracts, Review of Economic Studies 70, 281-315.

King, G. and Zeng, L. (2001) Logistic regression in rare events data, Political Analysis 9, 137-163.

Lerner, J. (1994) The syndication of venture capital investments, Financial Management 23, 16-27.

Lerner, J., Schoar, A. and Wong, W. (2007) Smart institutions, foolish choices? The limited partner performance puzzle, Forthcoming in The Journal of Finance.

Moskowitz, T. and Vissing-Jørgensen, A. (2002) The returns to entrepreneurial investment: A private equity premium puzzle? American Economic Review 92, 745-778.

Nenova, T. (2003) The value of corporate voting rights and control: A cross-country analysis, Journal of Financial Economics 68, 325-351.

O’Neal, F. H. (1987) Oppression of minority shareholders: Protection minority rights, Close Corporations Law Symposium, Cleveland State Law Review 35, 121-146.

O'Neal, F. H. and Thompson, R. (1985) O'Neal's Oppression of Minority Shareholders, Callaghan Lawyers Cooperative Publishing, Wilmette, Illinois.

Pagano, M. and Röell, A. (1998) The choice of stock ownership structure: Agency costs, monitoring and the decision to go public, The Quarterly Journal of Economics 113, 187-225.

Petersen, M. A. and Rajan, R. G. (1994) The benefits of lending relationships: Evidence from small business data, The Journal of Finance 49, 3-37. 
Phalippou, L. and Zollo M. (2005) What Drives Private Equity fund Performance, unpublished working paper, University of Amsterdam, INSEAD.

Pichler, P. and Wilhelm, W. (2001) A theory of the syndicate: Form follows function, The Journal of Finance 56, 2237-2264.

Sah, R. K. and Stiglitz, J. E. (1986) The architecture of economic systems: Hierarchies and polyarchies, American Economic Review 76, 716-727.

Shleifer, A. and Vishny, R. W. (1997) A survey of corporate governance, The Journal of Finance 52, 737-783.

Vækstfonden (2003) The Danish Market for Venture Capital and Buy-out (2003), Copenhagen, Denmark.

Wilson, R. B. (1968) The theory of syndicates, Econometrica 36, 119-132.

Wong, A. (2002) Angel Finance: The Other Venture Capital, unpublished working paper, University of Chicago.

Woodward, S. E. (2005) Measuring Risk and Performance for Private Equity, unpublished working paper, Sand Hill Econometrics. 